\title{
Soil phosphorus status and $P$ nutrition strategies of European beech forests on carbonate compared to silicate parent material
}

\author{
Jörg Prietzel (D) Jaane Krüger · Klaus Kaiser • Wulf Amelung • \\ Sara L. Bauke · Michaela A. Dippold • Ellen Kandeler • Wantana Klysubun • \\ Hans Lewandowski - Sebastian Löppmann · Jörg Luster · Sven Marhan • \\ Heike Puhlmann • Marius Schmitt • Maja B. Siegenthaler • Jan Siemens • \\ Sandra Spielvogel $\cdot$ Sabine Willbold $\cdot$ Jan Wolff $\cdot$ Friederike Lang
}

Received: 6 August 2021 / Accepted: 12 December 2021 / Published online: 2 February 2022

(C) The Author(s) 2022

\begin{abstract}
Sustainable forest management requires understanding of ecosystem phosphorus (P) cycling. Lang et al. (2017) [Biogeochemistry, https://doi.org/ 10.1007/s10533-017-0375-0] introduced the concept of P-acquiring vs. P-recycling nutrition strategies for European beech (Fagus sylvatica $L$.) forests on silicate parent material, and demonstrated a change from $\mathrm{P}$-acquiring to P-recycling nutrition from P-rich to P-poor sites. The present study extends this silicate
\end{abstract}

Responsible Editor: Edith Bai.

Supplementary Information The online version contains supplementary material available at https://doi.org/10.1007/ s10533-021-00884-7.

J. Prietzel ( $\square)$

Chair of Soil Science, School of Life Sciences

Weihenstephan, Technical University Munich, Emil-

Ramann-Str. 2, 85354 Freising, Germany

e-mail:prietzel@wzw.tum.de

J. Krüger · F. Lang

Professur für Bodenökologie, Albert-Ludwigs-Universität

Freiburg, Bertoldstr. 17, 79085 Freiburg, Germany

K. Kaiser

Soil Sciences, Martin Luther University Halle Wittenberg,

Von-Seckendorff-Platz 3, 06120 Halle (Saale), Germany

W. Amelung · S. L. Bauke · J. Wolff

Institute für Nutzpflanzenwissenschaften und

Ressourcenschutz (INRES), Allgemeine Bodenkunde und Bodenökologie, Universität Bonn, Nussallee 13,

53115 Bonn, Germany rock-based assessment to forest sites with soils formed from carbonate bedrock. For all sites, it presents a large set of general soil and bedrock chemistry data. It thoroughly describes the soil P status and generates a comprehensive concept on forest ecosystem P nutrition covering the majority of Central European forest soils. For this purpose, an Ecosystem P Nutrition Index $\left(E N I_{P}\right)$ was developed, which enabled the comparison of forest $\mathrm{P}$ nutrition strategies at the carbonate sites in our study among each other and also with those of the silicate sites investigated by Lang et al. (2017). The P status of forest soils on carbonate substrates was characterized by low soil $\mathrm{P}$ stocks and a large fraction of organic Ca-bound $\mathrm{P}$ (probably largely Ca phytate) during early stages of pedogenesis. Soil P stocks,

W. Amelung $\cdot$ H. Lewandowski $\cdot$ S. Willbold Institut für Bio- und Geowissenschaften - IBG-3: Agrosphäre, Forschungszentrum Jülich $\mathrm{GmbH}$, WilhelmJohnen-Straße, 52428 Jülich, Germany

M. A. Dippold · S. Löppmann · M. Schmitt Biogeochemie der Agrarökosysteme, Georg-AugustUniversität Göttingen, Büsgenweg 2, 37077 Göttingen, Germany

E. Kandeler · S. Marhan Institut für Bodenkunde und Standortslehre, Fachgebiet Bodenbiologie, Universität Hohenheim, Emil-Wolff-Str. 27, 70593 Stuttgart, Germany 
particularly those in the mineral soil and of inorganic $\mathrm{P}$ forms, including $\mathrm{Al}-$ and $\mathrm{Fe}$-bound $\mathrm{P}$, became more abundant with progressing pedogenesis and accumulation of carbonate rock dissolution residue. Phosphorus-rich impure, silicate-enriched carbonate bedrock promoted the accumulation of dissolution residue and supported larger soil $\mathrm{P}$ stocks, mainly bound to $\mathrm{Fe}$ and $\mathrm{Al}$ minerals. In carbonate-derived soils, only low $\mathrm{P}$ amounts were bioavailable during early stages of pedogenesis, and, similar to P-poor silicate sites, $\mathrm{P}$ nutrition of beech forests depended on tight (re)cycling of $\mathrm{P}$ bound in forest floor soil organic matter (SOM). In contrast to P-poor silicate sites, where the ecosystem $\mathrm{P}$ nutrition strategy is direct biotic recycling of SOM-bound organic $\mathrm{P}$, recycling during early stages of pedogenesis on carbonate substrates also involves the dissolution of stable $\mathrm{Ca}-\mathrm{P}_{\text {org }}$ precipitates formed from phosphate released during SOM decomposition. In contrast to silicate sites, progressing pedogenesis and accumulation of P-enriched carbonate bedrock dissolution residue at the carbonate sites promote again P-acquiring mechanisms for ecosystem $\mathrm{P}$ nutrition.

Keywords Calcareous soils - Ecosystem nutrition · Soil P forms · Pedogenesis - Bedrock impurity $\cdot \mathrm{P}$ acquiring $\cdot \mathrm{P}$ recycling

\section{Introduction}

Several recent studies (e.g. Prietzel and Stetter 2010; Talkner et al. 2015; Jonard et al. 2015; Prietzel et al.

W. Klysubun

Synchrotron Light Research Institute, 111 Moo 6

University Avenue, Muang District,

Nakhon Ratchasima 30000, Thailand

S. Löppmann · S. Spielvogel

Institut für Pflanzenernährung und Bodenkunde, Christian-Albrechts-Universität zu Kiel, Abteilung Bodenkunde, Hermann-Rodewaldstr. 2, 24118 Kiel, Germany

\section{J. Luster}

Forest Soils and Biogeochemistry, Swiss Federal Research Institute WSL, 8903 Birmensdorf, Switzerland
2020) reported increasing phosphorus (P) limitation of European forests. These trends highlight the need for improved understanding of ecosystem $\mathrm{P}$ nutrition strategies to support the development of P-sustainable forest management. For forests on siliceous substrates, Lang et al. (2016) proposed the concept of ecosystems acquiring $\mathrm{P}$ on sites with sufficient lithogenic $\mathrm{P}$ sources (apatite) vs. P-recycling ecosystems characterized by $\mathrm{P}$ bound to soil organic matter (SOM) at sites with little lithogenic $\mathrm{P}$ in the rooting zone. The usefulness of the approach was highlighted by Lang et al. (2017), who identified parameters allowing for rating the relative contribution of the two strategies for $\mathrm{P}$ nutrition in temperate forest ecosystems on silicate parent material. Phosphorus-acquiring ecosystems had larger soil P stocks and accumulated moderately labile $\mathrm{P}$ in topsoil horizons. With decreasing soil $\mathrm{P}$ stocks and increasing relevance of ecosystem $\mathrm{P}$ recycling, forest floor turnover rates decreased, while $\mathrm{C} / \mathrm{P}$ ratios in the $\mathrm{Oa}$ and $\mathrm{A}$ horizons increased. Moreover, $\mathrm{P}$ in fine-root biomass increased relative to microbialbound P. High proportions of fine-root biomass in forest floors seemed to favor tight $\mathrm{P}$ recycling. Intense $\mathrm{P}$ recycling improved the $\mathrm{P}$ use efficiency of beech forests on silicate parent material.

Forests on soils formed from carbonate bedrock often feature pronounced P limitation. This is particularly true where the parent material is low in $\mathrm{P}$ (Porder and Ramachandran 2013), and where soils are at an early stage of pedogenesis (e.g. Rendzic Leptosols) with $\mathrm{pH}$ values $>6.5$ and carbonate in the entire profile (Baier et al. 2006; Prietzel and Ammer 2008; Prietzel et al. 2015). Current assumptions on reasons for the poor $\mathrm{P}$ nutrition of forests on carbonate sites follow several lines of argument. Soil $\mathrm{P}$

H. Puhlmann

Forstliche Versuchs- und Forschungsanstalt BadenWürttemberg, Wonnhaldestr. 4, 79100 Freiburg, Germany

M. B. Siegenthaler

Institute of Agricultural Sciences, ETH Zurich, Eschikon 33, 8315 Lindau, Switzerland

J. Siemens

Professur für Bodenressourcen und Bodenschutz, Institut für Bodenkunde und Bodenerhaltung, Interdisziplinäres Forschungszentrum (iFZ), Justus-Liebig-Universität Giessen, Heinrich-Buff-Ring 26-32, 35392 Gießen, Germany 
contents are generally smaller in shallow, stony Rendzic Leptosols than in most soils developed from silicate parent material (Schubert 2002; Prietzel et al. 2015). Furthermore, orthophosphate $\left(\mathrm{oPO}_{4}\right)$ released by chemical weathering of lithogenic carbonateentrapped apatite $\left[\mathrm{Ca}_{5}(\mathrm{OH})\left(\mathrm{PO}_{4}\right)_{3}\right]$ immediately reprecipitates most often as sparsely soluble secondary Ca- $\mathrm{PO}_{4}$ minerals (Hinsinger 2001) and/or is strongly adsorbed to carbonate mineral surfaces (Wan et al. 2016). In principle, when access to inorganic $P$ is limited, enzymatic cleavage of SOM-bound organic $\mathrm{P}$ $\left(\mathrm{P}_{\text {org }}\right)$ is an important process of plant $\mathrm{P}$ acquisition (Hinsinger 2001), also known for $\mathrm{N}$ (e.g. Turner et al. 2014). However, even though $P$ mineralization rates are potentially high at elevated $\mathrm{pH}$ values, there is increasing evidence (McKercher and Anderson 1989; Celi et al. 2000; Crea et al. 2006; Celi and Barberis 2007; Wan et al. 2016; Prietzel et al. 2016a) that not only $\mathrm{oPO}_{4}$, but also several dissolved organic P (DOP) forms like inositol $\mathrm{P}$ strongly bind to the abundant $\mathrm{Ca}^{2+}$ ions in the soil solution, soil matrix, and bedrock. Overall, sparsely soluble und thus poorly bioavailable Ca-bound organic $\mathrm{P}$ (e.g. Ca inositol phosphates [" $\mathrm{Ca}$ phytate"] and inositol phosphates adsorbed to carbonate rock surfaces, Celi et al. 2000) are major $P$ forms in temperate carbonate forest soils (Prietzel et al. 2016b).

Walker and Syers (1976) developed a fundamental concept how stocks of total $\mathrm{P}$ and different $\mathrm{P}$ forms in soils systematically change with pedogenesis, affecting ecosystem $\mathrm{P}$ supply. According to this concept, $\mathrm{P}$ from bedrock-bound primary minerals (mostly apatite) is transformed into $\mathrm{P}_{\text {org }}$ and $\mathrm{P}$ bound to secondary minerals at initial stages of pedogenesis. This transformation is associated with continuous soil and ecosystem $\mathrm{P}$ losses. With progressing pedogenesis and ecosystem maturation, $\mathrm{P}$ mobilization from primary minerals in the rooted zone of soils is becoming increasingly irrelevant and replaced by transformation of the remaining soil $\mathrm{P}$ into hardlybioavailable organic and/or secondary mineral-bound soil $\mathrm{P}$ forms. During this process, the native ecosystem slowly changes from $\mathrm{N}$ to $\mathrm{P}$ limitation. The concept originally had been developed for temperate-humid soils on silicate substrate in New Zealand. Later, it has been proven true also for silicate soils under coolhumid (e.g. Giguet-Covex et al. 2013; Prietzel et al. 2013), semiarid (Selmants and Hart 2010), and subtropical climate (Chen et al. 2015). Furthermore, it has been modified for soils subject to high aeolic $\mathrm{P}$ input (Heindel et al. 2017; Gu et al. 2019), and for soils under cold polar climate (Prietzel et al. 2019). According to these studies, depending on site conditions, the time of change in soil $\mathrm{P}$ forms as predicted by the Walker and Syers (1976) model may vary between only decades for forests under temperate moist climate (Prietzel et al. 2013; Turner et al. 2013) up to several million years for grasslands under semi-arid climate (Selmants and Hart 2010). However, so far, no study on pedogenesis effects on the $\mathrm{P}$ status of soils derived from carbonate parent material has been published, and it remains unclear whether the concept of Walker and Syers (1976) is also valid for carbonate soils. In this study, we investigated forest soils developed from carbonate parent material using the same set of variables as in the study on silicate soils by Lang et al. (2017). We assume that (1) the poor P status of forests on carbonate parent material is at least partly caused by the small $\mathrm{P}$ stocks and/or peculiar $\mathrm{P}$ speciation of their soils (Prietzel et al. 2015; 2016b), and that (2) in contrast to initial silicate soils (Crews et al. 1995; Wardle et al. 2004), initial carbonate soils often show particularly poor P supply (Ewald, 2000; Prietzel and Ammer, 2008; Prietzel et al. 2015). Based on the overall assumption that the $\mathrm{P}$ nutrition strategy of beech forest ecosystems is controled by the P supply of soils, we further assume that (3) the concept for $\mathrm{P}$-acquiring and recycling and the indicators can also be applied to soils developing from carbonate parent material. We thus addressed the following hypotheses:

- The concept of Walker and Syers (1976) describing changes of soil $\mathrm{P}$ stocks and $\mathrm{P}$ forms with progressing pedogenesis is also valid for soils formed on carbonate parent material.

- Temperate forest soils formed from carbonate substrate differ from those formed from silicate parent material in terms of stocks and $\mathrm{P}$ speciation: The soils from carbonate bedrock are characterized by generally smaller total $\mathrm{P}$ stocks, and predominance of sparsely soluble Ca-bound organic P, resulting in poor ecosystem $\mathrm{P}$ availability and high relevance of soil $\mathrm{P}_{\text {org }}$ turnover for ecosystem $\mathrm{P}$ nutrition.

- The concept of P-acquiring vs. P-recycling ecosystems developed for temperate forests at silicate sites by Lang et al. $(2016 ; 2017)$ is also applicable for carbonate sites. 


\section{Materials and methods}

\section{Study sites}

The study was conducted at four sites with European beech (Fagus sylvatica L.)-dominated forests on soils developed from different carbonate parent materials (dolostone, limestone) and different stages of pedo-

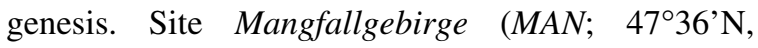
$\left.11^{\circ} 49^{\prime} \mathrm{E}\right)$ is located in the German Limestone Alps. It consists of two beech-dominated mixed mountain forest (F. sylvatica, Picea abies, Abies alba, Acer pseudoplatanus) stands, one covering the $\mathrm{N}$-exposed and one the opposing S-exposed slope of the Lange $\mathrm{Au}$ valley. The parent material of soil formation is dolostone. Site Tuttlingen (TUT; 47 ${ }^{\circ} 59^{\prime} \mathrm{N}, 8^{\circ} 45^{\prime} \mathrm{E}$ ) is located in the Swabian Alb (SW Germany). It consists of two mature beech forest stands, one covering the NE-exposed and one the opposing SW-exposed slope of the Krähenbach valley. The parent material of soil formation is limestone. At MAN (Biermayer and Rehfuess 1985) and also at TUT, pedogenesis started after the end of the last glaciation, i.e. about 12,000 years ago; pre-Pleistocene soils had been removed by periglacial solifluction. The third site Bärenthal $\left(B A E ; 48^{\circ} 4^{\prime} \mathrm{N}, 8^{\circ} 55^{\prime} \mathrm{E}\right)$ is located on a plateau in the Swabian Alb at $16 \mathrm{~km}$ distance to TUT. It consists of a mature beech forest with admixed $A$. pseudoplatanus, A. alba, and P. abies. The parent material is also limestone. The flat topography has resulted in conservation of soil material formed by intensive chemical weathering during the Neogene (Stahr and Böcker 2014). The soils at TUT SW (shallow Rendzic Leptosol), TUT NE (Rendzic Leptosol with more advanced pedogenesis and a BA horizon), and $B A E$ (Cambisol with thick $\mathrm{B}$ horizon) are located within $16 \mathrm{~km}$ distance from each other. They have similar parent material, climate, and forest vegetation (Table 1), but represent a series of progressing pedogenesis. The fourth site is Schänis

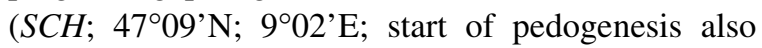
about 12,000 years ago), located in the Swiss Alps in Canton St. Gallen at a W-exposed slope. It is covered by mature mountain forest dominated by $F$. sylvatica. The climatic conditions are more humid and cool than at TUT, but drier and warmer than at MAN. The bedrock at $\mathrm{SCH}$ are Neogene sediments and carbonate conglomerate. Detailed information on all study sites, their soils, and bedrock chemistry is presented in
Tables 1, 2 and Table S1 in the Supplementary Information. Note that despite high carbonate contents in bedrock (Table S1), in the weathered soil A horizons the contents of $\mathrm{Al}$ and $\mathrm{Fe}$ exceeded those of $\mathrm{Mg}$ and $\mathrm{Ca}$, pointing to clays and oxyhydroxides as bonding sites for P apart from cation bridges. Briefly, all sites had carbonate parent material, but differed in (i) carbonate type and purity (dolostone at MAN, limestone at $T U T$ and $B A E$, mixture of limestone and silicate parent material at $S C H$ ), (ii) time of pedogenesis (limestone site $T U T<<B A E$ ), microclimate $(\mathrm{N}$ exposed sites at MAN and TUT were cooler and moister than their S-exposed counterparts), and bedrock $\mathrm{P}$ content (TUT $S W<T U T N E)$.

Methods

We tested our hypotheses by investigating the carbonate-derived soils applying the exactly same methods of sampling, pretreatment, and analysis as used before by Lang et al. (2017) and Prietzel et al. (2016b: XANES studies) for the silicate-derived soils. We (i) characterized the carbonate-derived soils regarding contents and stocks of total $\mathrm{P}$ and different $\mathrm{P}$ forms. Moreover, we (ii) compared their P status with that of silicate-derived soils under similar climate and vegetation cover. Furthermore, we (iii) assessed the $\mathrm{P}$ nutrition strategy of the forest ecosystems on the carbonate sites.

\section{Soil sampling and pretreatment}

For all soil analyses except microbial biomass and enzyme analysis (see below), we used soil samples derived from volume-based sampling of a complete soil profile performed over an area of $0.25-0.56 \mathrm{~m}^{2}$, down to the consolidated bedrock or $100 \mathrm{~cm}$ depth, whichever was reached first. Due to the high stone content of all soils except of $B A E$, we used the "'quantitative soil pit' (QP) approach developed by Hamburg (1984) as modified by Vadeboncoeur et al. (2012). By analyzing a soil volume with a large cross section representing a large portion of the rooting space of an adult tree, QP sampling provides a more coherent representation of the system than analysis of several small soil volumes. We established four pits at $M A N$, two pits at TUT, and one pit at $S C H$. Details of the QP approach and our soil sampling procedure are reported in the Supplementary Information. At $B A E$, 


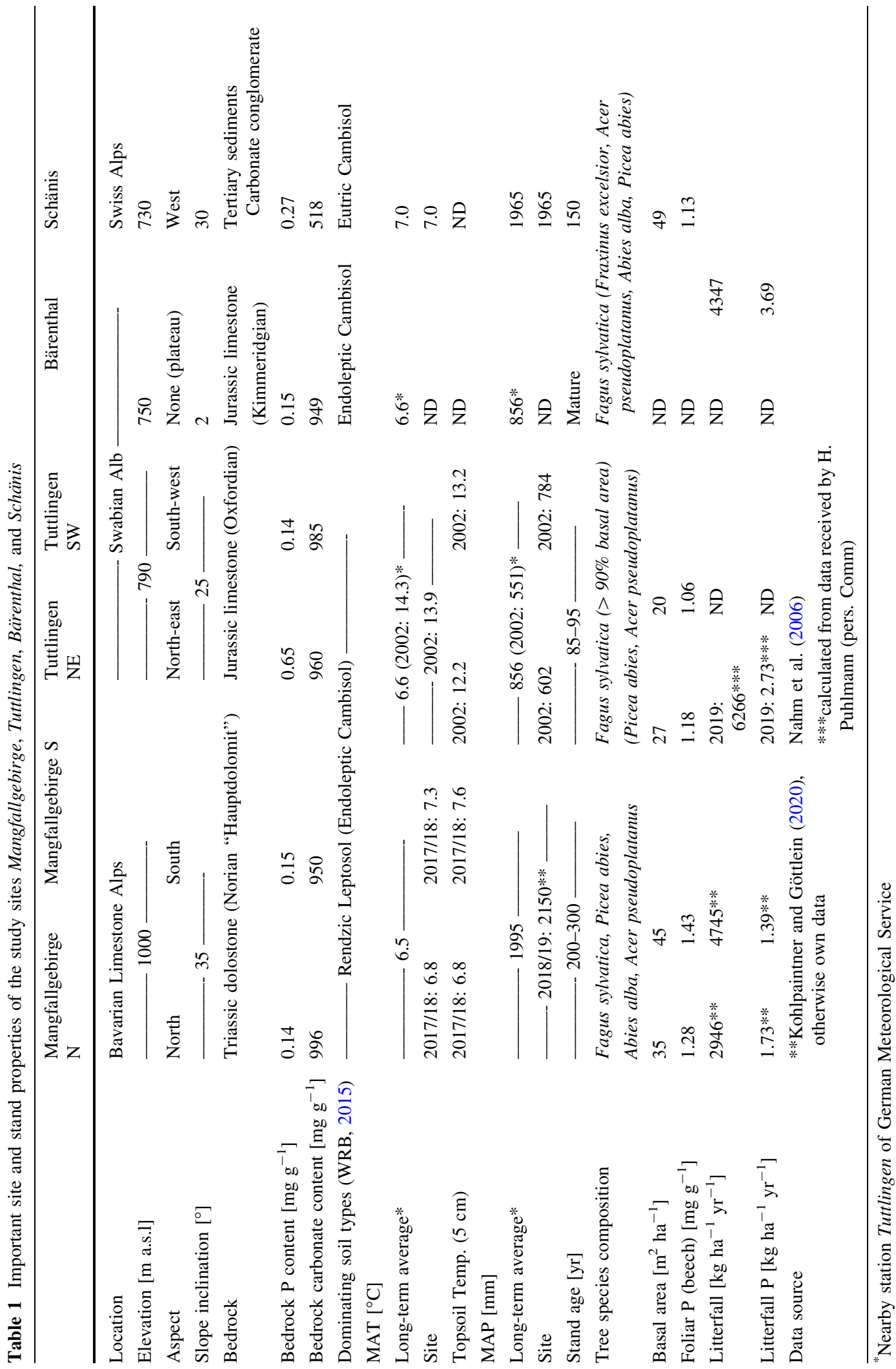




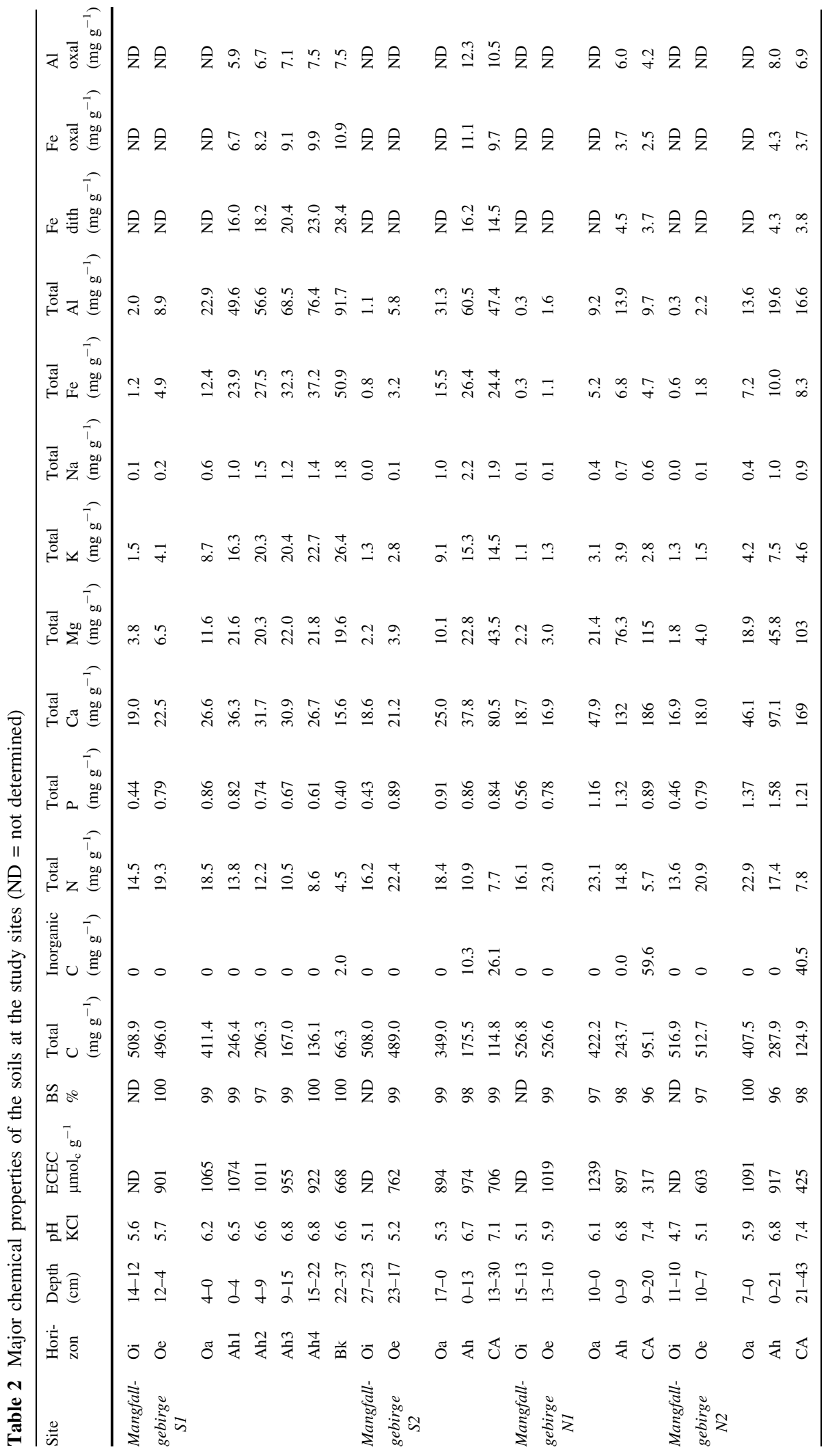




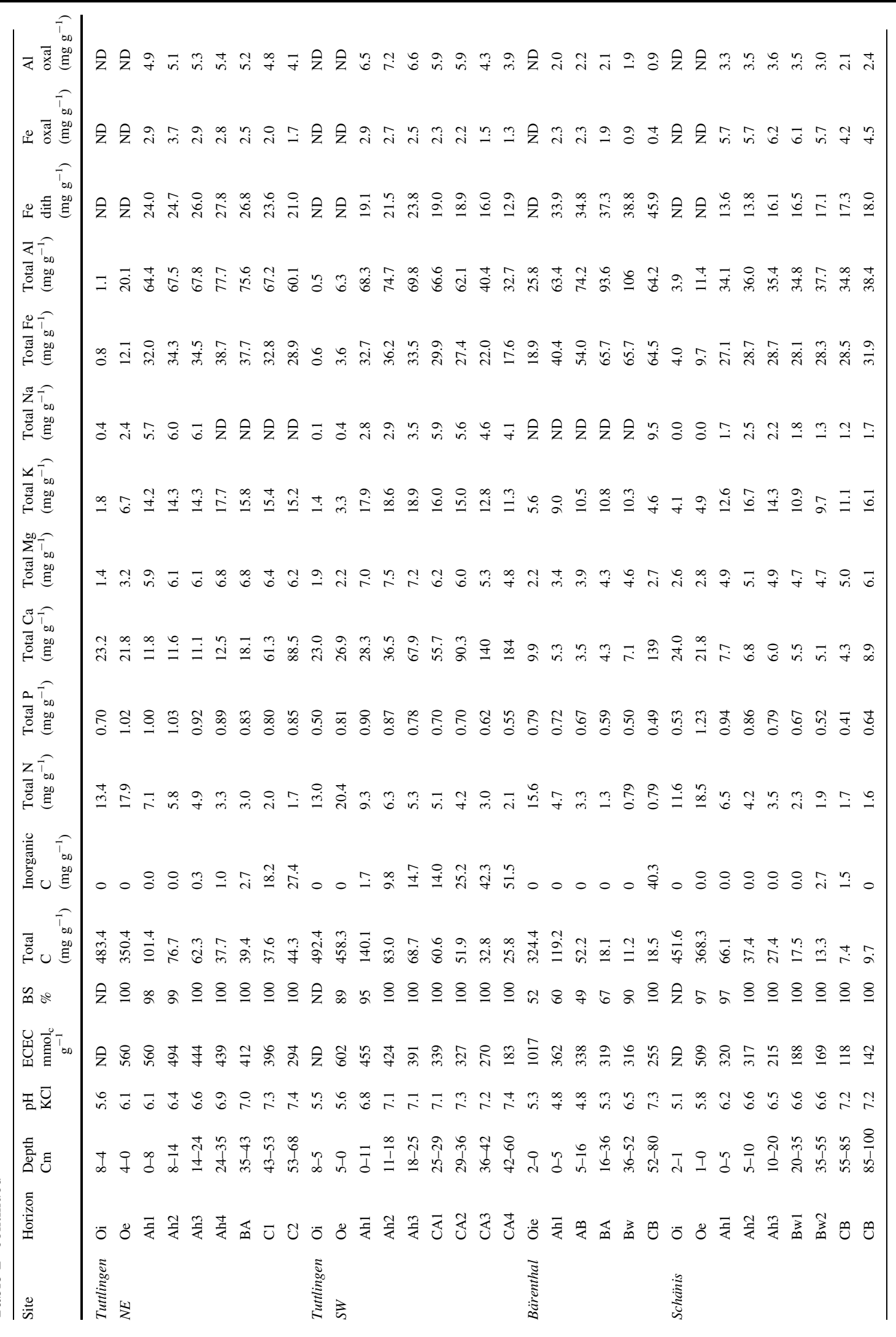


soil material for chemical analyses was sampled from the face of a profile. Bulk density and coarse fragment data were taken from Stahr and Böcker (2014). For microbiological and enzyme analyses, we sampled $\mathrm{Oe}, \mathrm{Oa}$, and Ah material at representative locations at $<1 \mathrm{~m}$ distance of the QPs. All microbiological and enzyme samples were frozen immediately after sampling with solid $\mathrm{CO}_{2}$ ("dry ice") and kept frozen until analysis.

\section{Determination of total element contents}

Total contents of $\mathrm{P}, \mathrm{K}, \mathrm{Ca}, \mathrm{Mg}, \mathrm{K}, \mathrm{Na}, \mathrm{Al}, \mathrm{Fe}, \mathrm{Mn}$, and $\mathrm{Ti}$ in all soil samples were analyzed by digestion of fine-ground subsamples with a mixture of concentrated $\mathrm{HClO}_{4} / \mathrm{HNO}_{3} / \mathrm{HF}$ (Jackson 1958; Lim and Jackson 1982) and analysis by inductively coupled plasma-optical emission spectrometry ICP-OES (Varian Vista-Pro CCD).

\section{Determination of different soil $P$ forms}

Wet-chemical determination of organic, inorganic, and plant-available $P$

We analyzed organic $\mathrm{P}\left(\mathrm{P}_{\text {org }}\right)$ by extracting sieved soil samples with $0.5 \mathrm{M} \mathrm{H}_{2} \mathrm{SO}_{4}$ before and after ignition at $550{ }^{\circ} \mathrm{C}$ (Saunders and Williams 1955). Organic $\mathrm{P}$ was calculated as difference of orthophosphate $\left(\mathrm{oPO}_{4}\right)$ determined in extracts from ignited and respective non-ignited subsamples, using the malachite green colorimetric method (Ohno and Zibilske 1991). Uncertainties related to this approach are discussed in Lang et al. (2017). Plant-available P was extracted from sieved soil samples with $0.5 \mathrm{M} \mathrm{NaHCO} 3$ adjusted to $\mathrm{pH} 8.5$ with $\mathrm{NaOH}$ (Olsen et al. 1954). Orthophosphate-P in the $\mathrm{NaHCO}_{3}$ extracts was analyzed photometrically, using the ascorbic acid method of Murphy and Riley (1962) as modified by John (1970), and total P in the extracts was analyzed by ICP-OES. The difference between $\mathrm{OPO}_{4}-\mathrm{P}$ and total $\mathrm{P}$ was assumed to be organic P.

\section{P K-edge XANES spectroscopy}

On fine-ground mineral soil samples, we acquired $\mathrm{P}$ K-edge X-ray absorption near-edge spectroscopy (XANES) spectra at beamline 8 of the Synchrotron Light Research Institute (SLRI) in Nakhon
Ratchasima, Thailand (Klysubun et al. 2012; 2019). The instrument is equipped with a $\mathrm{InSb}(111)$ doublecrystal monochromator (energy resolution $\Delta \mathrm{E} / \mathrm{E}$ : $3 * 10^{-4}$ ), which was calibrated with elemental $\mathrm{P}$ $\left(\mathrm{E}_{0}=2145.5 \mathrm{eV}\right)$. We recorded all spectra in fluorescence mode with a 13 -element Ge detector. For each sample, depending on its $\mathrm{P}$ content, we acquired between two and five spectra. The spectra were deconvoluted for quantification of different soil $\mathrm{P}$ species by linear combination fitting (LCF) according to Werner and Prietzel (2015). For LCF, we used spectra of the reference compounds $\mathrm{FePO}_{4}, \mathrm{AlPO}_{4}$, hydroxy apatite, $\mathrm{CaHPO}_{4}$, phytic acid $\mathrm{Na}$ salt hydrate (IHP), Ca phytate, $\mathrm{Fe}(\mathrm{III})$ phytate, $\mathrm{oPO}_{4}$ as well as IHP adsorbed to boehmite, ferrihydrite, and Al-saturated montmorillonite (Prietzel et al. 2016a). All standards were diluted with fine-ground quartz to $2 \mathrm{mg} \mathrm{P} \mathrm{g}^{-1}$ to avoid self-absorption. Phosphorus speciation shares $<5 \%$ of total $\mathrm{P}$ were excluded from the result list, and LCF was repeated without the respective standard. To improve LCF accuracy and precision, we used the averages of the five "best" results with the smallest R factors according to Eriksson et al. (2015). The K-edge XANES spectra of inorganic and organic $\mathrm{P}$ adsorbed to the same mineral are very similar (Prietzel et al. 2016a) and thus hard to quantify by LCF (Gustafsson et al. 2020). For proper identification of these $\mathrm{P}$ forms, we therefore combined the XANES $\mathrm{P}$ speciation data with the results of the wet-chemical determination of organic and inorganic P (see Supplementary Information).

\section{Hedley fractionation}

We analyzed sieved soil samples using the sequential extraction method of Hedley et al. (1982) as modified by Tiessen and Moir (1993). For each sample, we extracted $0.5 \mathrm{~g}$ soil with solutions of increasing $\mathrm{P}$ mobilization strength. We started with deionized water containing an anion exchange resin (Dowex 18, 20-50 mesh, Sigma-Aldrich, Taufkirchen, Germany). This was followed by extractions with $0.5 \mathrm{M}$ $\mathrm{NaHCO}_{3}, 0.1 \mathrm{M} \mathrm{NaOH}, 1 \mathrm{M} \mathrm{HCl}$, concentrated $\mathrm{HCl}$ $(7 \mathrm{M})$, and a final digestion with $65 \% \mathrm{HNO}_{3} / 37 \% \mathrm{HCl}$ (aqua regia). Orthophosphate concentrations in the extracts were determined according to Murphy and Riley (1962). Fractions were combined to estimate the following P pools (Niederberger et al. 2019): Labile P: $\mathrm{P}$ extractable by resin or $\mathrm{NaHCO}_{3}$; Moderately labile 
P: P extractable by $\mathrm{NaOH}$ or $1 \mathrm{M} \mathrm{HCl}$; Stable P: $\mathrm{P}$ mobilized by $\mathrm{HCl}$ (conc.) or aqua regia digestion.

\section{${ }^{31}$ P NMR spectroscopy}

The speciation of organic $\mathrm{P}$ in the Ah horizons of soils $M A N$ and TUT was analyzed by ${ }^{31} \mathrm{P}-\mathrm{NMR}$ spectroscopy of soil NaOH-EDTA extracts. The method and key results have already been described by Wang et al. (2020). Briefly, we extracted the samples with $0.25 \mathrm{M} \mathrm{NaOH}$ plus $0.05 \mathrm{M} \mathrm{Na}_{2}$-EDTA $(1: 1 \mathrm{v} / \mathrm{v})$ according to Cade-Menun (2005). Then we centrifuged the samples $(1500 \times \mathrm{g}, 20 \mathrm{~min})$, and split the supernatant into two equal portions. One portion was lyophilized directly (Thermo Freeze Dryer, Heto PowerDry PL6000). The second portion was dialyzed (molecular weight cutoff: 14,000; thickness: $0.041 \mathrm{~mm}$; Visking, Cellulose, Roth, (Sumann et al. 1998; Amelung et al. 2001). Subsequent sample preparation for NMR spectroscopy included resolving the freeze-dried extracts in $1 \mathrm{ml}$ aqua dest. and additionally $0.5 \mathrm{ml} \mathrm{D}_{2} \mathrm{O}$ and $10 \mathrm{M} \mathrm{NaOH}$ in order to increase and standardize the $\mathrm{pH}$ for optimal peak separation (Crouse et al. 2000). Then we centrifuged all samples $(1500 \times \mathrm{g}, 20 \mathrm{~min})$ und decanted the supernatants into NMR tubes. For spectra acquisition, we used a Varian $600 \mathrm{MHz}$ spectrometer equipped with a $5 \mathrm{~mm}$ broadband probe tuned to the ${ }^{31} \mathrm{P}$ nucleus. Other parameters were listed as: $45^{\circ}$ pulse calibrated at $6.0 \mu \mathrm{s}, 0.4 \mathrm{~s}$ acquisition time, $5 \mathrm{~s}$ total relaxation delay, 15,800 scans, proton inverse-gated decoupling, and a temperature of $293.15 \mathrm{~K}$. Chemical shifts of signals were measured in parts per million (ppm) relative to $85 \% \mathrm{H}_{3} \mathrm{PO}_{4}$. For each sample, we acquired approximately 25,000 scans. All spectra were recorded with a line broadening of $3.0 \mathrm{~Hz}$. Terminology and interpretation of the spectra followed CadeMenun (2005; 2015), Bol et al. (2006), and Vincent et al. (2013). We analyzed the spectra as described by Turner (2004).

\section{Determination of microbial $P$}

Microbial biomass $\mathrm{P}\left(\mathrm{P}_{\text {mic }}\right)$ was determined on selected samples of MAN N1, TUT NW, and SCH in triplicate using anion-exchange resin membranes by simultaneous liquid fumigation and extraction (Kouno et al. 1995) with hexanol instead of liquid chloroform (Bünemann et al. 2004). Four gram of field-moist soil were shaken together with resin and distilled water either with hexanol or without, subsequently eluting the resin with $0.1 \mathrm{M} \mathrm{NaCl} / \mathrm{HCl}$. The $\mathrm{P}$ concentration in the eluate was determined by the malachite green method (Ohno and Zibilske 1991). We determined $\mathrm{P}_{\text {mic }}$ according to Bünemann et al. (2016) using Eq. 1:

$P_{\text {mic }}=\left(P_{\text {fum }}-P_{\text {resin }}\right) / P_{\text {rec }}$

where $\mathrm{P}_{\text {fum }}$ and $\mathrm{P}_{\text {resin }}$ are the concentrations of $\mathrm{P}$ (in $\mathrm{mg}$ $\mathrm{P} \mathrm{kg}^{-1}$ ) extracted from fumigated and non-fumigated subsamples, respectively, and $\mathrm{P}_{\text {rec }}$ is the fraction of the added $\mathrm{P}$ spike that is recovered on the resin membranes, which is calculated following Eq. 2:

$P_{\text {rec }}=\left(P_{\text {spike }}-P_{\text {resin }}\right) / P_{\text {spike }}^{*}$

where $\mathrm{P}_{\text {spike }}$ is the $\mathrm{P}$ concentration measured in the $\mathrm{P}$-spiked subsample and $\mathrm{P}^{*}$ spike is the amount of $\mathrm{P}$ added with the spike (both in $\mathrm{mg} \mathrm{P} \mathrm{kg} \mathrm{kg}^{-1}$ ). In accordance with Bünemann et al. (2016) we present $\mathrm{P}_{\text {mic }}$ without the use of a conversion factor which could account for incomplete extraction of microbial $P$ since this factor is method- and soil-dependent (Oberson and Joner 2005) but was not determined in our study.

\section{Assessment of bacterial and fungal biomass}

The relative contribution of bacterial and fungal biomass to total microbial biomass in $\mathrm{Oe}, \mathrm{Oa}$, and Ah horizons of the study soils was estimated by phospholipid fatty acid (PLFA) analysis conducted on field-moist samples. Fungal and bacterial PLFAs were determined according to Bligh and Dyer (1959) with modifications as described by White et al. (1979) and Bardgett et al. (1996). Gram-positive bacterial biomass was quantified using the fatty acids i15:0, a15:0, i16:0, and i17:0. Gram-negative bacterial biomass was quantified using the fatty acids cy 17:0 and cy 19:0. For total bacterial PLFAs, the sum of gram-positive and gram-negative bacterial fatty acids as well as of the fatty acid 16:1 17 were used (Frostegård et al. 1993). For fungal biomass (accounting for saprotrophic fungi

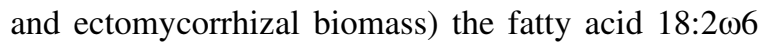
was used (Federle et al. 1986). 
Determination of acid phosphomonoesterase and phosphodiesterase activities

Acid phosphomonoesterase (EC 3.1.3.2) activity was determined using a modified disodium phenylphosphate method. Briefly, each soil sample (field-moist, stored at $-20{ }^{\circ} \mathrm{C}$ and sieved) was split into three subsamples and two controls of $1 \mathrm{~g}$ each. Soil suspensions were prepared with $10 \mathrm{ml}$ acetate buffer (pH 5) and $5 \mathrm{ml} 20 \mathrm{mM}$ disodium phenylphosphate (EC 3279-54-7) as substrate solution; in controls, substrate solution was replaced by deionized water. All suspensions were incubated at $37{ }^{\circ} \mathrm{C}$ and continuous shaking (100 rpm) for $3 \mathrm{~h}$. The release of phenol was determined colorimetrically at $614 \mathrm{~nm}$ (ELx808, Absorbance Microplate Reader, BioTek Instruments, Winooski, VT, USA), using 2,6-dibromquinone-chlorimide (EC 202-937-2) as coloring reagent (Hoffmann 1968, modified by Öhlinger 1996). Phosphodiesterase activity (EC 3.1.4.1) was measured using bis(pnitrophenyl) phosphate (EC 223-739-2) as substrate and bis(hydroxymethyl) aminomethane as the $p$ nitrophenol color reagent according to a modified procedure of Margesin (1996). Each fresh soil sample was split into three subsamples and two controls of each $1 \mathrm{~g}$. Soil suspensions were prepared with $4 \mathrm{ml}$ $0.05 \mathrm{M}$ Tris(THAM) buffer (pH 8.0) and $1 \mathrm{ml} 5 \mathrm{mM}$ substrate solution. In controls, substrate solution was replaced by deionized water. Soil suspensions were incubated at $37^{\circ} \mathrm{C}$ for $1 \mathrm{~h}$ at continuous shaking (100 rpm). After incubation, $1 \mathrm{ml} 0.5 \mathrm{M} \mathrm{NaCl}$ solution and $4 \mathrm{ml} 0.1 \mathrm{M}$ Tris(THAM) buffer ( $\mathrm{pH}$ 12.0) were added to each subsample, whereas the controls received additionally $1 \mathrm{ml}$ of the substrate solution. Soil suspensions were filtered and pipetted into 96-well microplate (PS F transparent 96 well; Greiner Bio-one, Frickenhausen, Germany). The enzyme activity was measured photometrically at $405 \mathrm{~nm}$ on a micro-plate reader (ELx808, BioTek Instruments, Winooski, VT, USA).

\section{Isotopic exchange kinetics}

For determination of isotopic exchange kinetics (IEK), we added a given amount of $\mathrm{H}_{3}{ }^{33} \mathrm{PO}_{4}$ to a preequilibrated (i.e. steady-state conditions for $\mathrm{P}$ ) soil:water (100 ml:10 g) suspension and measured the decrease of radioactivity in the solution over time. At the end of the experiment (after $90 \mathrm{~min}$ ), we determined water extractable $\mathrm{P}\left(P_{w}\right)$ after filtration of the soil solution $(0.2 \mu \mathrm{m})$ using the malachite green method (Ohno and Zibilske 1991). The decrease in solution concentration of the initially added ${ }^{33} \mathrm{P}$ can be described by Eq. 3 (Fardeau 1993)

$r_{t} / R=m \times\left(t+m^{1 / n}\right)^{-n}+r_{\infty} / R$

where $r_{t}$ and $r_{\infty}(\mathrm{MBq})$ are the radioactivity remaining in solution after $t$ min and after an infinite time of isotopic exchange, respectively. $R(\mathrm{MBq})$ is the initially added radioactivity, $t(\mathrm{~min})$ is the time elapsed after radioactivity addition, and $m$ and $n$ are soil-specific parameters calculated from a non-linear regression between $r_{t} / R$ and $t$ after Frossard and Sinaj (1997). The $r_{\infty} / R$ value is estimated as the ratio of water extractable $\mathrm{P}$ to total inorganic $\mathrm{P}$ (both in $\mathrm{mg} \mathrm{P}$ $\mathrm{kg}^{-1}$ ). As described by Fardeau (1993), the amount of isotopically exchangeable $\mathrm{P}\left(E_{t}\right.$, in $\mathrm{mg} \mathrm{P} \mathrm{kg}^{-1}$ soil $)$ is calculated using Eq. 4 as described by Fardeau (1993):

$E_{t}=P_{w} \times\left(R / r_{t}\right)$

We calculated the following variables: $m, n, \mathrm{P}_{\mathrm{w}}$ and the amounts of $\mathrm{P}$ isotopically exchangeable within 1 min $\left(E_{1 \text { min }}, \mathrm{mg} \mathrm{P} \mathrm{kg}^{-1}\right.$ soil), between $1 \mathrm{~min}$ and 1 day $\left(E_{\text {lmin-1 day }}\right)$, between 1 day and 3 months $\left(E_{\text {lday-3 months }}\right)$. Additionally, we calculated the amount of $\mathrm{P}$ that cannot be exchanged within 3 months $\left(E_{>3}\right.$ months $)$ by taking the difference between total inorganic $\mathrm{P}$ obtained by extraction following Saunders and Williams (1955) and $E_{3 m o n t h s}$.

\section{Other soil variables with relevance for the soil P status}

Contents of total soil carbon (C) and nitrogen (N) were determined on dried $\left(105{ }^{\circ} \mathrm{C}\right)$, sieved $(2 \mathrm{~mm})$, and fine-ground samples using an elemental analyzer (Vario EL cube, Elementar, Hanau, Germany). On subsamples, inorganic $\mathrm{C}$ (carbonate) contents were determined by excess addition of $4 \mathrm{M} \mathrm{HCl}$ and quantification of the released $\mathrm{CO}_{2}$ using a calcimeter (Eijkelkamp, Giesbeek, The Netherlands). The pH of air-dried, sieved samples was determined in deionized water and in $1 \mathrm{M} \mathrm{KCl}$ at soil:solution ratios of 1:2.5 $(\mathrm{w} / \mathrm{v})$. Cation exchange capacity (CEC) and exchangeable cations were determined using $\mathrm{NH}_{4}$ acetate at $\mathrm{pH}$ 7 and $\mathrm{KCl}$ (Hendershot et al. 2008). Concentrations of extracted $\mathrm{Ca}, \mathrm{Mg}, \mathrm{K}$, and $\mathrm{Na}$ were analyzed by ICPOES (Ultima 2, Horiba Jobin-Yvon, Longjumeau, 
France). $\mathrm{NH}_{4}{ }^{+}$in the $\mathrm{KCl}$ extracts was determined using an automated photometer (SANplus, Skalar Analytical, Breda, The Netherlands). The difference between the CEC and the sum of $\mathrm{Ca}, \mathrm{Mg}, \mathrm{K}$, and $\mathrm{Na}$ is an estimate of $\mathrm{H}^{+}$and $\mathrm{Al}^{3+}$ occupation of the CEC. We applied the hot dithionite-citrate-bicarbonate extraction method of Mehra and Jackson (1960) to estimate total pedogenic $\mathrm{Fe}$ oxyhydroxides $\left(\mathrm{Fe}_{\mathrm{d}}\right)$. Extraction with $\mathrm{NH}_{4}$ oxalate at $\mathrm{pH} 3.0$ and $2 \mathrm{~h}$ shaking in the dark (Schwertmann 1964) was carried out to estimate $\mathrm{Al}$ and $\mathrm{Fe}$ in organic complexes and short range-ordered $(\mathrm{SRO})$ minerals $\left(\mathrm{Al}_{\mathrm{o}} ; \mathrm{Fe}_{\mathrm{o}}\right)$. Concentrations of extracted $\mathrm{Al}$ and $\mathrm{Fe}$ were analyzed by ICPOES. Soil microbial biomass $\mathrm{C}$ and $\mathrm{N}\left(\mathrm{C}_{\text {mic }} ; \mathrm{N}_{\text {mic }}\right)$ were determined using the chloroform fumigation extraction (CFE) method (Brookes et al. 1985; Vance et al. 1987). Non-fumigated, moist soil (7 g) was extracted with $30 \mathrm{ml} 0.05 \mathrm{M} \mathrm{K}_{2} \mathrm{SO}_{4}$ for $1 \mathrm{~h}$ (Bruulsema and Duxbury 1996) by overhead shaking (40 rev $\min ^{-1}$ ). A similar amount of soil was fumigated with ethanol-free chloroform and extracted in the same way. The fumigation was carried out in desiccators at $20{ }^{\circ} \mathrm{C}$ for $24 \mathrm{~h}$. The organic $\mathrm{C}$ content of the extracts was measured using a $\mathrm{CN}$ analyzer $(2100 \mathrm{~S}$, Analytik Jena). Microbial biomass $\mathrm{C}$ and $\mathrm{N}$ were calculated by dividing the microbial $\mathrm{C}$ or $\mathrm{N}$ flush $\left(\mathrm{E}_{\mathrm{C}} ; \mathrm{E}_{\mathrm{N}}\right)$; the difference between extracted $\mathrm{C}$ or $\mathrm{N}$ from fumigated and non-fumigated soil samples with $\mathrm{k}_{\mathrm{EC}}$ or $\mathrm{k}_{\mathrm{EN}}$ factor of 0.45 (Wu et al. 1990).

\section{Conversion of element and $P$ species contents into soil stocks}

Contents of various soil constituents in different soil horizons were converted into stocks by multiplying the content data with the surface area-standardized soil mass of a given horizon as retrieved by the QP approach and in the case of $B A E$ with the data reported by Stahr and Böcker (2014). The stock values of the various horizons comprising a soil profile were summed up to yield the total soil stock.

\section{Assessment of ecosystem P nutrition strategy}

The type of ecosystem $\mathrm{P}$ nutrition (P-acquiring vs. Precycling; Lang et al. 2016; 2017) was assessed for all eight carbonate soil profiles. For each profile, we calculated the values of the three indicators for $\mathrm{P}$ acquisition and of the four indicators for $\mathrm{P}$ recycling
(Table 3) as described by Lang et al. (2017). Due to limited data availability, N2 and N3 could only be calculated for four carbonate sites, and N6 only for two sites. To enable comparison of the different indicators among the carbonate soils and also between carbonate and silicate soils, we normalized the indicator values obtained for each carbonate profile as in the study of Lang et al. (2017), using Eq. 5.

$N_{a i}=\frac{I_{a i}}{I_{a m}}$

where $N$ represents the normalized indicator value, the index $a$ the indicator addressed, the index $i$ the study site, and $I$ the indicator value. The index $m$ represents the P-richest site on silicate bedrock (Bad Brückenau; BBR), characterized as P-acquiring ecosystem, and the P-poorest site on silicate parent material (Lüss; LUE) characterized as P-recycling ecosystem. For an overall estimate of the $\mathrm{P}$ nutrition strategy of each carbonate and silicate site, we first calculated the arithmetic mean of the three $\mathrm{P}$ acquisition indicator values obtained for the individual sites. Then, we referenced the average $P$ acquisition indicator to the range of average $\mathrm{P}$ acquisition indicators of the silicate sites. Their respective average $\mathrm{P}$ acquisition indicators were defined as $1(B B R=$ silicate site with maximum $\mathrm{P}$ supply; $\mathrm{P}$-acquiring) and 0 $(L U E=$ silicate site with minimum $\mathrm{P}$ supply; $\mathrm{P}$ recycling; Lang et al. 2017). Accordingly, we calculated the arithmetic mean of the four $\mathrm{P}$ recycling indicator values for each site, and referenced it to the range of average $\mathrm{P}$ recycling indicators of silicate sites, with that of $B B R$ defined as 0 and that of $L U E$ defined as 1 . Finally, an ecosystem $P$ nutrition index $\left(E N I_{P}\right)$ was calculated for each site by subtracting the referenced mean $\mathrm{P}$ recycling indicator from the referenced mean $\mathrm{P}$ acquisition indicator of each site. Thus, the $\mathrm{P}$ nutrition strategy of each site was related to a scale ranging from $E N I_{P}=+1$ (acquiring endmember $B B R$ of silicate sites) to -1 (recycling endmember $L U E$ of silicate sites). A positive $E N I_{P}$ indicates predominance of $\mathrm{P}$-acquiring over P-recycling, whereas a negative $E N I_{P}$ indicates predominance of P-recycling over P-acquiring. 
Table 3 Indicators for ecosystem P-acquisition and P-recycling, method of calculation of indicator values and justification of indicator (from Lang et al. 2017)

\begin{tabular}{|c|c|c|}
\hline $\begin{array}{l}\text { Variable } \\
\mathrm{P} \text { acquiring indicators }\end{array}$ & Calculation of indicator values & Assumed underlying process \\
\hline $\begin{array}{l}\text { N1: P-enrichment in } \\
\text { topsoil }\end{array}$ & $\begin{array}{l}\mathrm{P} \text { stock in the upper } 50 \% \text { of soil fine earth mass } \\
\text { divided by total soil } \mathrm{P} \text { stock (up to } 1 \mathrm{~m} \text { ) }\end{array}$ & $\begin{array}{l}\text { Spatial redistribution induced by the } \mathrm{P} \text { pumping of } \\
\text { trees in the long term: root uptake of } \mathrm{P} \text { in the } \\
\text { subsoil, } \mathrm{P} \text { deposition with litter at the topsoil and } \\
\text { adsorption after mineralization }\end{array}$ \\
\hline $\begin{array}{l}\text { N2: Proportion of } \\
\text { nonstable } \mathrm{P} \text { in profile }\end{array}$ & $\begin{array}{l}\text { Stock (up to } 1 \mathrm{~m} \text { ) of non-stable } \mathrm{P} \text {. (i.e., sum of } \\
\text { Hedley } \mathrm{P} \text { minus } \mathrm{P}_{\mathrm{HCl} \text { conc }} \text { and } \mathrm{P}_{\text {residual }} \text { ) relative to } \\
\text { total Hedley } \mathrm{P}\end{array}$ & $\begin{array}{l}\text { Chemical redistribution due to biological } \\
\text { mobilization of P from primary minerals. Nutrient } \\
\text { demand had been discussed as the reason for root } \\
\text { induced weathering }\end{array}$ \\
\hline $\begin{array}{l}\text { N3: Phosphate } \\
\text { exchangeability } \\
\text { between } 1 \text { min and } \\
1 \text { day }\end{array}$ & $\begin{array}{l}\text { Concentration of isotopically exchangeable P } \\
\text { between } 1 \text { min and } 1 \text { day of topsoil horizons as } \\
\text { described in methods chapter }\end{array}$ & $\begin{array}{l}\mathrm{P} \text { exchangeability based on physicochemical } \\
\text { processes; indicator for P availability }\end{array}$ \\
\hline \multicolumn{3}{|l|}{$\mathrm{P}$ recycling indicators } \\
\hline $\begin{array}{l}\text { N4: Accumulation of } \\
\mathrm{P} \text { in forest floor }\end{array}$ & $\begin{array}{l}\mathrm{P} \text { stock in the forest floor related to total P stock (up } \\
\text { to } 1 \mathrm{~m} \text { mineral soil depth) }\end{array}$ & $\begin{array}{l}\text { Forest floor pathways as short cut for plant } \mathrm{P} \text { uptake } \\
\text { without passing of } \mathrm{P} \text { through the fixing mineral } \\
\text { soil }\end{array}$ \\
\hline $\begin{array}{l}\text { N5: Concentration of } \\
\text { fine-root biomass in } \\
\text { forest floor }\end{array}$ & $\begin{array}{l}\text { Total fine root biomass in forest floor and upper } \\
0-5 \mathrm{~cm} \text { mineral soil in relation to total fine root } \\
\text { biomass (up to } 1 \mathrm{~m} \text { mineral soil depth) }\end{array}$ & $\begin{array}{l}\text { Peak concentrations of fine roots in the forest floor } \\
\text { have been assumed to favor tight } \mathrm{P} \text { cycling in acid } \\
\text { temperate forest ecosystems. Results are clearer } \\
\text { when the } 0-5 \mathrm{~cm} \text { increment of the mineral soil is } \\
\text { added }\end{array}$ \\
\hline $\begin{array}{l}\text { N6: Enrichment of } \\
\text { diester-P }\end{array}$ & $\begin{array}{l}\text { Diester-P/monoester-P ratio in the topsoil horizon as } \\
\text { calculated from NMR spectra }\end{array}$ & $\begin{array}{l}\text { Increased proportions of diester } \mathrm{P} \text { were observed in } \\
\text { acid soils and explained by changes in enzyme } \\
\text { activity, and decreased accessibility of diester P } \\
\text { for microbial decay due to accumulation within } \\
\text { large organic molecules }\end{array}$ \\
\hline $\begin{array}{l}\text { N7: Mean residence } \\
\text { time of forest floor } \\
\text { SOM }\end{array}$ & $\begin{array}{l}\text { Forest floor mass related to the mass of annual litter } \\
\text { fall }\end{array}$ & $\begin{array}{l}\text { Limited decay of soil organic matter enhances tight } \\
\mathrm{P} \text { recycling by providing forest floor P-pathways } \\
\text { for tree nutrition }\end{array}$ \\
\hline
\end{tabular}

\section{Results}

Total soil P contents and stocks

At all sites, total P contents (Table 2; Fig. 1) in the forest floor increased with depth and degree of SOM decomposition in the sequence Oi-Oe-Oa horizon, whereas those in the mineral soil decreased with depth. Total soil fine earth $P$ stocks ranged between 90 and $350 \mathrm{~g} \mathrm{~m}^{-2}$ (Fig. 2a). The relative contribution of $\mathrm{P}$ bound in coarse fragments to the total $\mathrm{P}$ in the profiles ranged from 5\% at MAN S1 to $42 \%$ at TUT SW. The forest floor comprised up to $44 \%$ of total soil (fine earth) $\mathrm{P}$ in the $\mathrm{P}$-poor MAN profiles, whereas its contribution was small $(<5 \%)$ in the other soils. The contribution of the topsoil (Ah horizons) to total soil (fine earth) $\mathrm{P}$ ranged between 11 and 56\%, while the subsoil (B, C horizons) contributed between 29 and $89 \%$ to total soil (fine earth) P. In the P-rich profiles $S C H$ and $B A E$ with advanced pedogenesis and thick $\mathrm{B}$ horizons, subsoil $\mathrm{P}$ strongly dominated the soil $\mathrm{P}$ pool.

\section{Contents and stocks of different soil $\mathrm{P}$ forms}

\section{Organic and inorganic $P$}

In all soil horizons organic $\mathrm{P}\left(\mathrm{P}_{\text {org }}\right)$ dominated over inorganic $\mathrm{P}\left(\mathrm{P}_{\text {inorg }}\right)$, and in almost all horizons $\mathrm{P}_{\text {org }}$ comprised $>70 \%$ of total $\mathrm{P}$ (Fig. 1). Organic $\mathrm{P}$ contents generally decreased with increasing mineral soil depth. In contrast, $\mathrm{P}_{\text {inorg }}$ contents often showed a secondary maximum in the deep subsoil, but were 
always smaller than $\mathrm{P}_{\text {org }}$ contents. Organic soil $\mathrm{P}$ stocks (Fig. 2b) ranged between 75 and $271 \mathrm{~g} \mathrm{~m}^{-2}$ and comprised between 66-70\% (in Cambisols $\mathrm{SCH}$ and $B A E$ ) and $90 \%$ (Rendzic Leptosol TUT SW), on average $77 \%$ of total soil (fine earth) P. Inorganic soil $\mathrm{P}$ stocks ranged between 13 and $108 \mathrm{~g} \mathrm{~m}^{-2}$ and comprised between $10 \%$ and $30-34 \%$ (SCH and $B A E$ ), on average $23 \%$, of total soil P (Fig. 2b).

\section{$P$ speciation in mineral soil horizons assessed by $P$ K-edge XANES spectroscopy}

According to $\mathrm{P}$ K-edge XANES (Fig. 1, Fig. 2c; Table S2), $\mathrm{P}_{\text {org }}$ in the mineral soil of the dolostonederived soils as well as in TUT SW and $S C H$ was predominantly Ca-bound. On average, about $60 \%$ of mineral soil fine earth $\mathrm{P}$ was Ca-bound; Fe-bound $\mathrm{P}$ and Al-bound $\mathrm{P}$ each constituted about 20\%. A difference in soil $\mathrm{P}$ speciation can be noticed between soils without B horizons (MAN N1, N2, S2; TUT SW) and soils with B horizons ( $M A N S 1, S C H$, particularly $B A E$ ) or impure carbonate bedrock (marl limestone at TUT NE). The latter soils had larger Fe-bound $\mathrm{P}$ stocks, which constituted the majority of fine earth $\mathrm{P}$ at $B A E$ and TUT NE.

\section{$\mathrm{NaHCO}_{3}$-extractable $\mathrm{P}$}

Contents of $\mathrm{NaHCO}_{3}$-extractable $\mathrm{P}$ (Table S2), which is an estimate for plant-available $\mathrm{P}$, decreased in the mineral soil with depth. Stocks of $\mathrm{NaHCO}_{3}$-extractable $\mathrm{OPO}_{4}$ (Fig. 3) ranged between $2(\mathrm{MAN} N \mathrm{Nl})$ and $15 \mathrm{~g} \mathrm{~m}^{-2}$ (MAN S2), those of $\mathrm{NaHCO}_{3}$-extractable $\mathrm{P}_{\text {org }}$ ranged between $0.2 \mathrm{~g} \mathrm{~m}^{-2}$ (MAN N1) and $9 \mathrm{~g} \mathrm{~m}^{-2}(\mathrm{SCH}) . \mathrm{NaHCO}_{3}$-extractable $\mathrm{P}$ was mostly $\mathrm{oPO}_{4}$ at $M A N$, to about equal shares $\mathrm{OPO}_{4}$ and $\mathrm{P}_{\text {org }}$ at $T U T$, and mostly $\mathrm{P}_{\text {org }}$ at $\mathrm{SCH}$.

\section{Hedley P fractions}

In almost all mineral soil samples, the majority of soil $\mathrm{P}$ could only be mobilized by treatment with concentrated $\mathrm{HCl}$ or aqua regia (Fig. 4; Table S3), and thus was in the stable fraction according to Niederberger et al. (2019). The contribution of stable $\mathrm{P}$ to total $\mathrm{P}$ increased with soil depth, whereas the contribution of labile $\mathrm{P}$ (resin-P, $\mathrm{NaHCO}_{3}$-extractable $\mathrm{P}$ fractions) decreased. Except for the subsoil at $\mathrm{SCH},<10 \%$ of soil $\mathrm{P}$ was moderately labile. Mineral soil stocks of stable $\mathrm{P}$ increased with soil development and were larger in limestone-derived than in dolostone-derived soils (Fig. 5). The contribution of labile $\mathrm{P}$ to total $\mathrm{P}$ decreased with progressing pedogenesis.

$P$ speciation in Ah horizons by ${ }^{31} P$ NMR spectroscopy

Contents of NaOH-EDTA-extractable $\mathrm{P}$ at MAN N1 and TUT NE were about 300 (L horizons), 500 (O, $\mathrm{Ah}$ ), and 200 (CAh) $\mathrm{mg} \mathrm{g}^{-1}$ soil (Fig. 6; Wang et al. 2020). Extraction recoveries as related to total $P$ contents of the respective horizons (shaded bars in Fig. 6) decreased with soil depth from $80-100 \%$ in L layers to $50-60 \%$ in $\mathrm{O}$ and $\mathrm{Ah}$ and $25 \%$ in $\mathrm{CAh}$ horizons. With $35-70 \%$ of extractable $\mathrm{P}$, monoester $\mathrm{P}$ was the dominating $\mathrm{P}$ form. Its contribution to total extractable $\mathrm{P}$ increased with depth. Between 1 and $11 \%$ of extractable $\mathrm{P}$ was phosphodiester $\mathrm{P}$ bound in DNA, and between 1 and $9 \%$ was lipid phosphodiester P. Orthophosphate constituted about $25 \%$ of extractable $\mathrm{P}$, and about $80 \%$ of extractable $\mathrm{P}_{\text {inorg }}$. Between 4 and $12 \%$ of extractable $P$ was pyrophosphate-P. Polyphosphate was only present in Oi layers (7-10\% of extractable P).

\section{Microbial bound $P$ and enzyme activities}

Contents of microbial $\mathrm{P}, \mathrm{C}$, and $\mathrm{N}\left(\mathrm{P}_{\text {mic }}, \mathrm{C}_{\text {mic }}, \mathrm{N}_{\text {mic }}\right)$ in all profiles significantly decreased with depth (Fig. 7; Figure $\mathrm{S} 2, \mathrm{~S} 3$ ). In the Ah horizons, $\mathrm{P}_{\text {mic }}$ contents increased in the sequence $S C H<M A N N 1<T U T$ $N E$. Mass ratios of $\mathrm{C}_{\text {mic }} / \mathrm{P}_{\text {mic }}$ decreased in the same order (Table 4). Phosphomonoesterase and phosphodiesterase activities also decreased with soil depth and on average were eight times (phosphomonoesterase) and three times (phosphodiesterase) larger in $\mathrm{O}$ than Ah horizons (Table 5). A larger decrease in phosphomonoesterase than phosphodi-esterase activities resulted in smaller phosphomonoesterase/phosphodiesterase ratios in A horizons than $\mathrm{O}$ layers.

\section{Isotopic exchange kinetics}

Water-extractable $\mathrm{P}_{\text {inorg }}$ contents $\left(\mathrm{P}_{\mathrm{w}}\right)$ at $M A N S 1$ and $S 2$, TUT NE, BAE, and $S C H$ ranged from 0.003 to $2.97 \mu \mathrm{g} \mathrm{P} \mathrm{g}^{-1}$ soil and decreased with increasing depth (Table 6). The fitting parameter $m$, accounting for immediate physicochemical reactions, followed the same trends as $\mathrm{P}_{\mathrm{w}}$ in TUT NE and $\mathrm{SCH}$. The fitting 

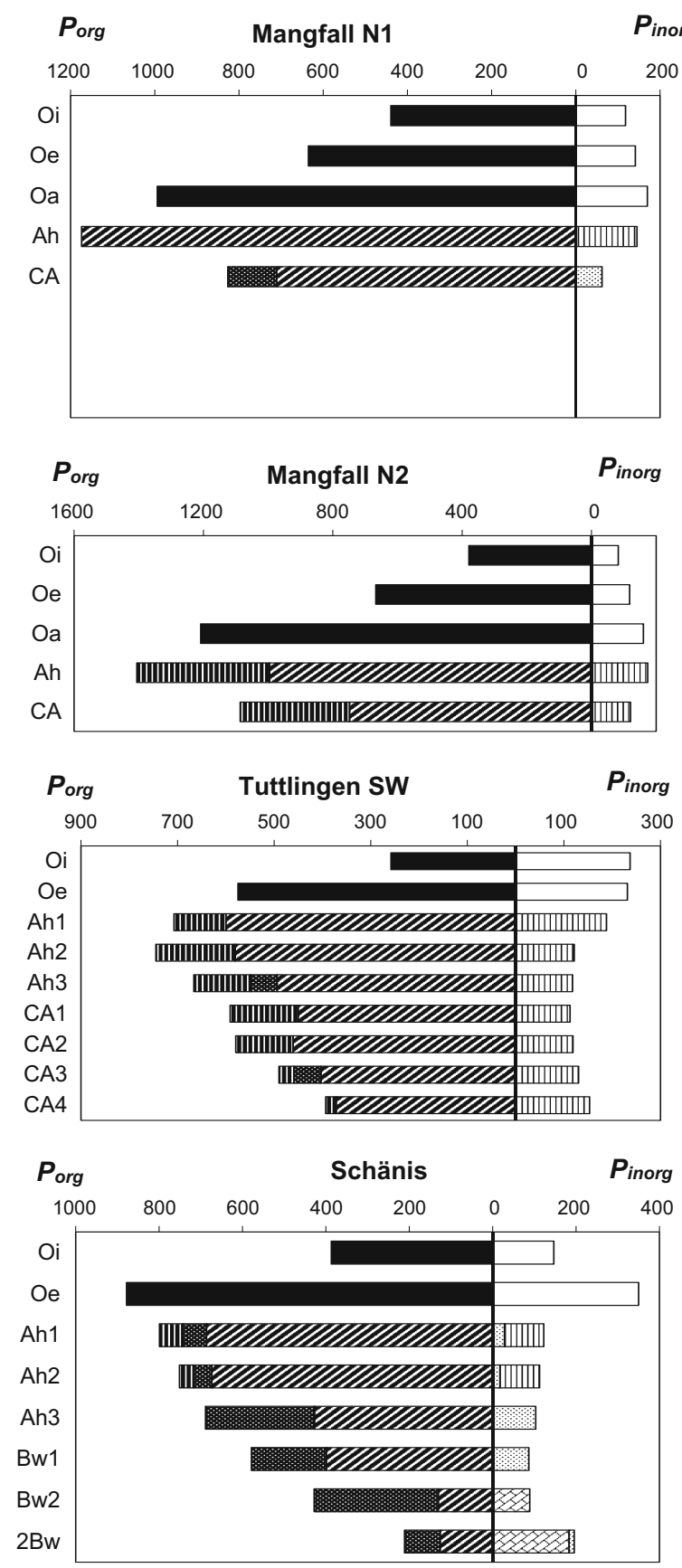

- Porg unspecified

Porg Ca-bound

$\square$ Pinorg unspecified

Pinorg Ca-bound
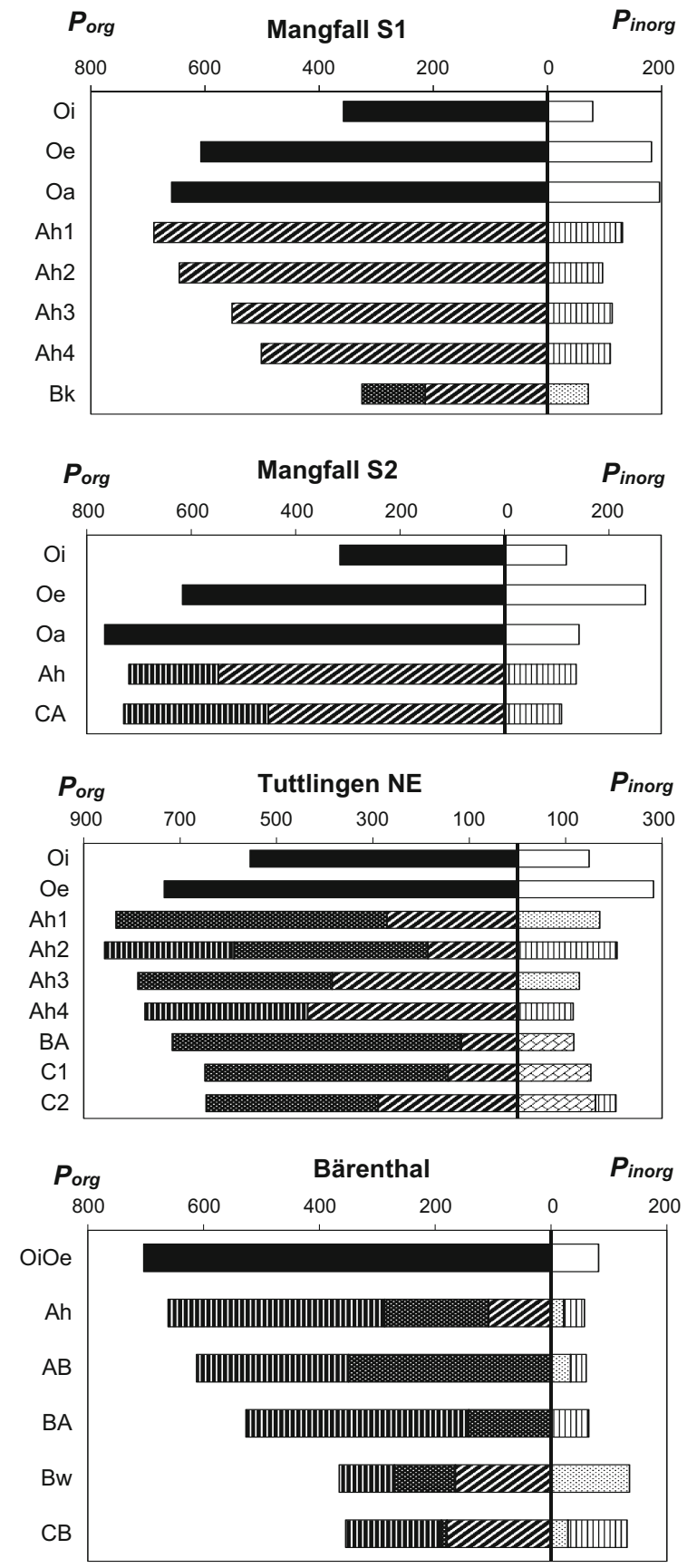

IIII Porg Al-bound

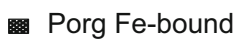

四 Pinorg Al-bound Pinorg Fe-bound

Fig. 1 P speciation of the soils at sites Mangfallgebirge, Tuttlingen, Bärenthal, and Schänis. Presented are contents of different organic $\mathrm{P}$ species (left from vertical zero axis) and inorganic $\mathrm{P}$ species (right from vertical zero axis) in $\mathrm{mg} \mathrm{P}^{-1} \mathrm{soil}^{-1}$ 

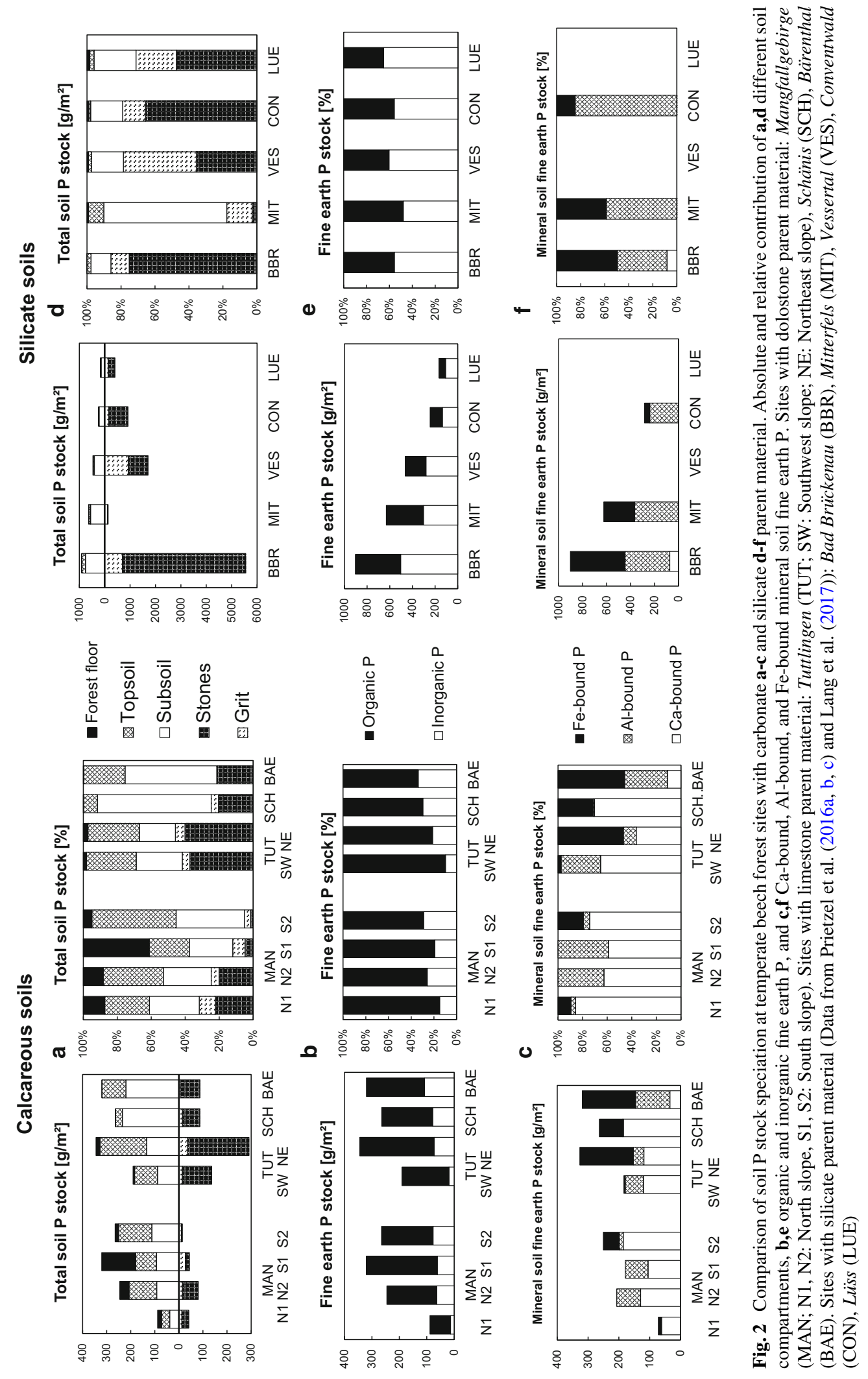

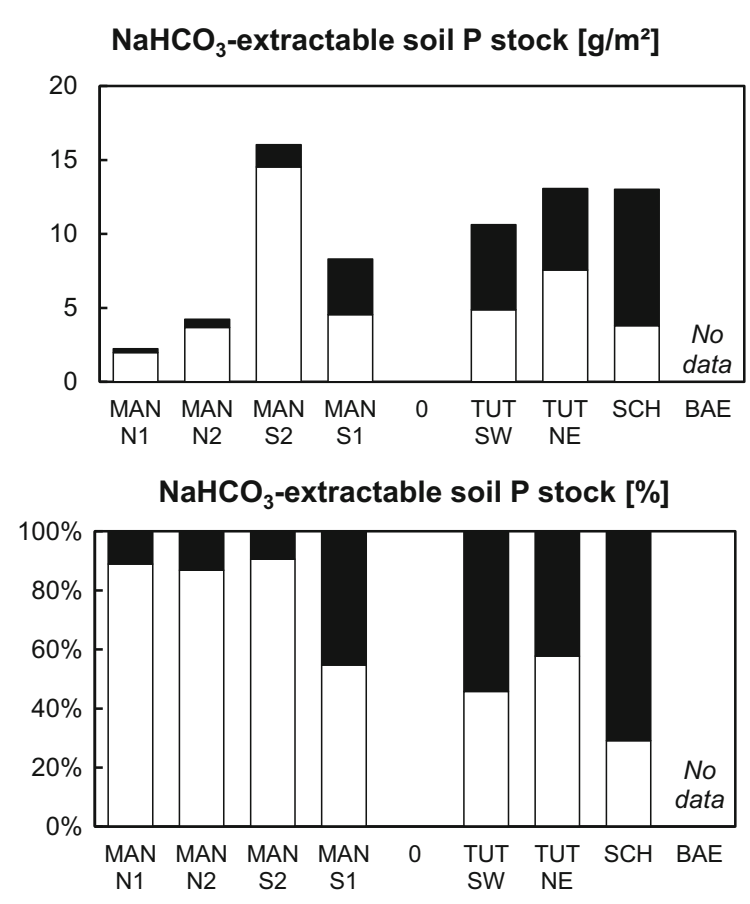

Fig. 3 Plant-available soil $\mathrm{P}$ stocks $\left(\mathrm{NaHCO}_{3}\right.$-extractable $\left.\mathrm{P}\right)$ at temperate beech forest sites with carbonate parent material. Shown are absolute and relative contributions of organic $\mathrm{P}$ (black bars) and inorganic P (white bars). For a detailed description of sites, please read caption of Fig. 2

parameter $n$, accounting for slow physicochemical reactions, was rather constant over depth at all four sites. The amount of $\mathrm{P}$ that was isotopically exchangeable between 1 day and 3 months ( $E_{1 \text { day-3 months }}$ ) decreased with increasing depth at all four sites. Profiles MAN S1 and S2 had largest amounts of isotopically exchangeable $\mathrm{P}$, and TUT NE (Ah) and $B A E(\mathrm{Bw})$ had largest amounts of non-isotopically exchangeable $\mathrm{P}$ ( $\mathrm{E}_{>3}$ months $)$.

Ecosystem $\mathrm{P}$ nutrition indicators and ecosystem $\mathrm{P}$ nutrition strategies

The seven indicators for $\mathrm{P}$ acquisition (N1-N3) and P recycling (N4-N7) calculated according to Lang et al. (2017) are presented in Table 7. For three of the four MAN profiles, the $\mathrm{P}$ recycling indicators $\mathrm{N} 4$ and $\mathrm{N} 7$ ranged between 1.3 and 8.5 and thus markedly exceeded the range of the silicate soils. Consequently, negative $E N I_{P}$ values indicated a dominance of $\mathrm{P}$ recycling over $\mathrm{P}$ acquisition at all dolostone sites (Table 7). Except for Cambisol MAN S1, ENI $P$ values at the dolostone sites were $<-1$. This indicates pronounced $\mathrm{P}$ recycling, exceeding even that of the most P-recycling silicate site LUE. Among the carbonate sites, $E N I_{P}$ was highly negatively correlated with forest floor P (and SOC) stocks, but not with total soil P stocks (Fig. 8). The limestone sites showed a change from predominating recycling to acquiring $\mathrm{P}$ nutrition with progressing pedogenesis.

\section{Discussion}

Many analytical methods applied in our study (e.g. NMR and XANES spectroscopy, Hedley P fractionation, determination of isotopic exchange kinetics) are costly and/or time demanding, preventing the analysis of replicate profiles at each study site. Therefore, our paper unfortunately does not allow for statistical analysis of soil P status differences among the various sites. Nevertheless, we think that our paper presents a lot of novel important information on the $\mathrm{P}$ status of soils with carbonate parent material, regarding effects of pedogenesis, bedrock carbonate purity, and differences to soils with silicate parent materials.

Changes of P stock, $\mathrm{P}$ speciation, and ecosystem $\mathrm{P}$ nutrition in soils on carbonate bedrock with progressing pedogenesis

Soils TUT SW (shallow Rendzic Leptosol), TUT NE (Rendzic Leptosol with more advanced pedogenesis and a BA horizon), and BAE (Cambisol with thick B horizon) are located within $16 \mathrm{~km}$ distance from each other. They have similar parent material, climate, and forest vegetation (Table 1), but represent a series of progressing pedogenesis. Whereas the two Leptosols have developed after the last Pleistocene glaciation, and their age is $<12,000$ years, Cambisol BAE is prePleistocene and has an age of at least 2.5 Ma (Stahr and Böcker 2014). This sequence provides novel information on changes in $\mathrm{P}$ stock and $\mathrm{P}$ speciation in carbonate soils with pedogenesis. In contrast to the chronosequences on silicate parent material studied by Walker and Syers (1976), the limestone soils showed increasing fine earth P stocks (Fig. 9) with increasing soil age and progressing pedogenesis (shallow Rendzic Leptosol Cambisol). The increase in fine earth P stock was mostly caused by an increase in soil depth, formation of subsoil horizons, and fine earth 
Fig. 4 Contents (left panels; $\mathrm{mg} \mathrm{P} \mathrm{kg}^{-1}$ ) and relative contribution (right panels) of different Hedley $\mathrm{P}$ fractions (labile $\mathrm{P}$ : resin $+\mathrm{NaHCO}_{3}$ extractable $\mathrm{P}$; moderately labile $\mathrm{P}: \mathrm{NaOH}-$

extractable $+1 \mathrm{M} \mathrm{HCl}-$

extractable P; stable P: 7 M $\mathrm{HCl}$-extractable + aqua regia-extractable $\mathrm{P}$ ) in different mineral soil horizons of profiles Mangfallgebirge N1 and S1, Tuttlingen NE, Schänis, and Bärenthal
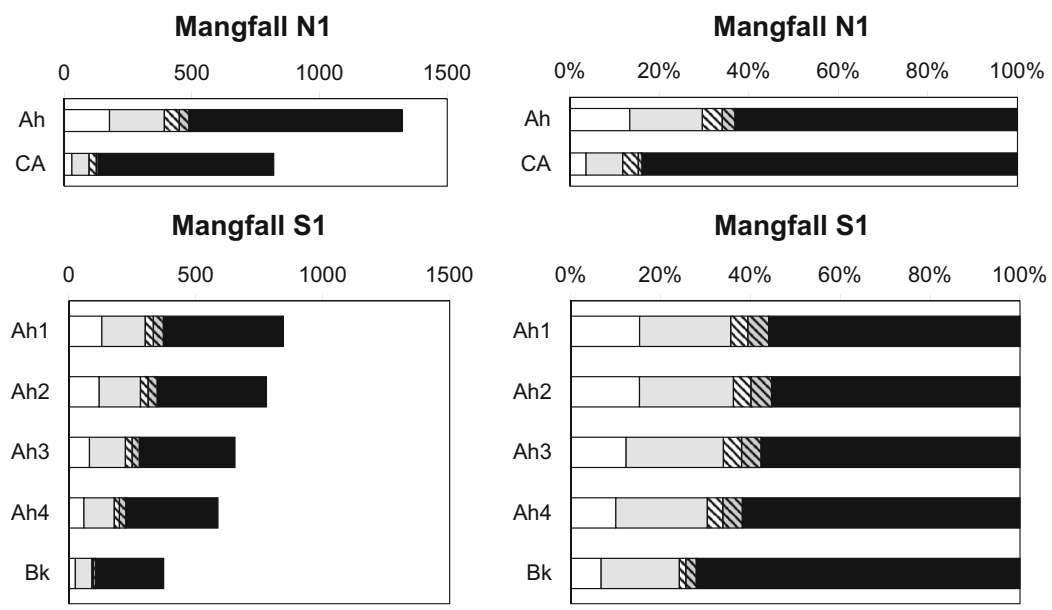

Tuttlingen NE
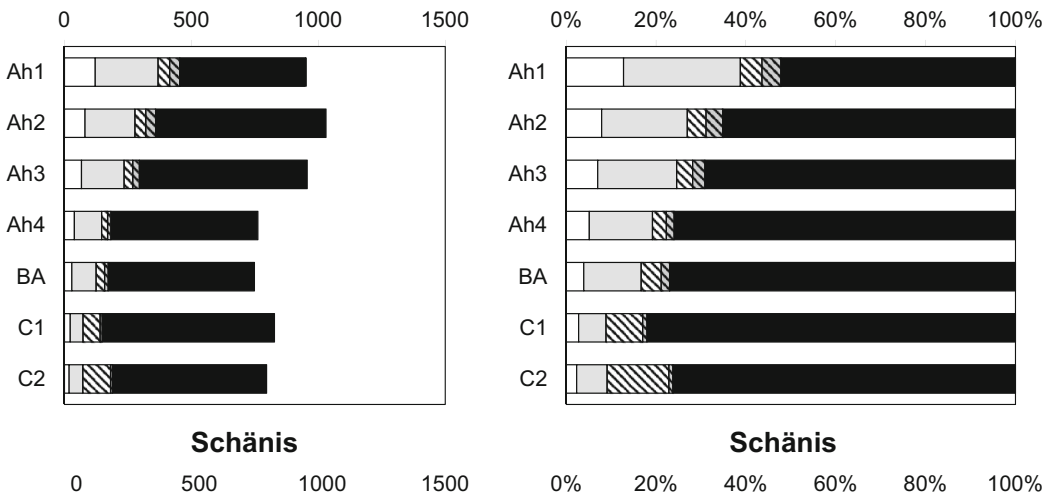

Schänis

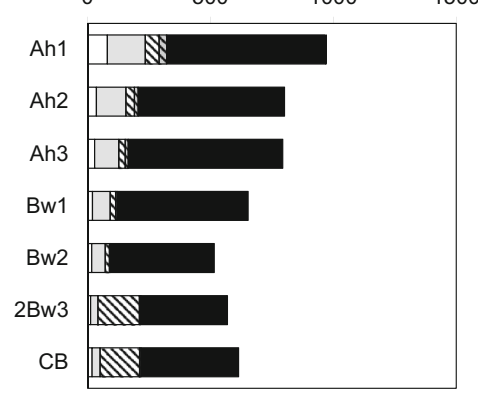

Bärenthal

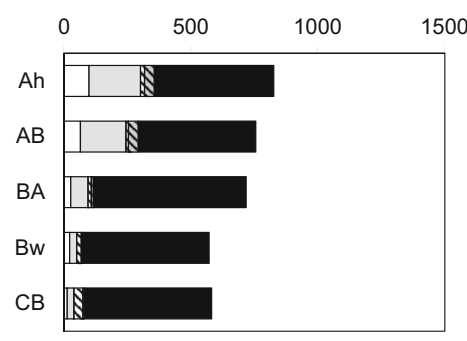

Labile Pinorg

Moderately labile Pinorg

Stable P

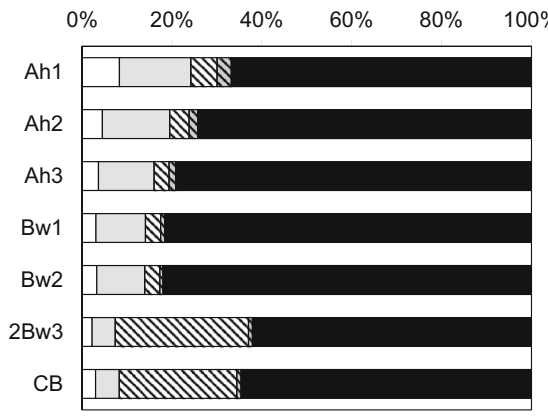

Bärenthal

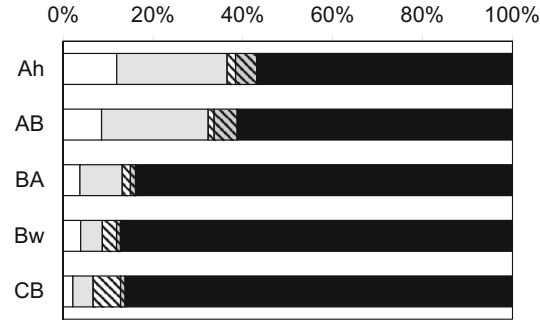

Labile Porg

Moderately labile Porg 
Fig. 5 Comparison of mineral soil stocks of different Hedley P fractions at temperate beech forest sites with carbonate (left panels) and silicate parent material (right panels; data from Lang et al. (2017). Shown are absolute and relative contributions of different Hedley P fractions in the investigated profiles
Carbonate soils

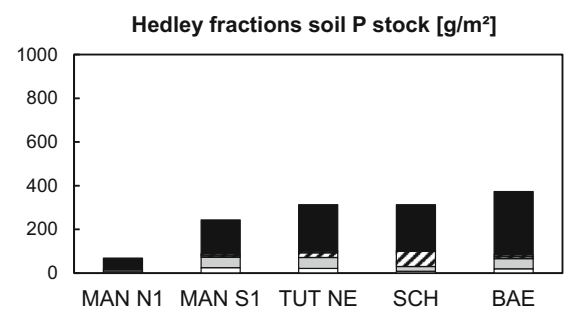

Hedley fractions soil P stock $\left[\mathrm{g} / \mathrm{m}^{2}\right]$

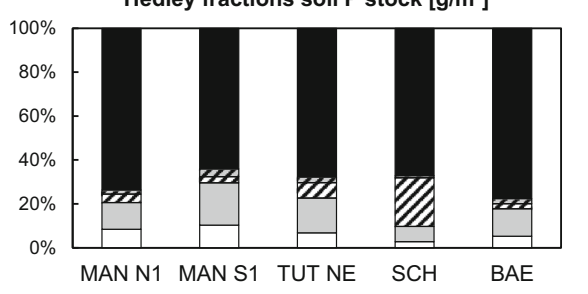

Silicate soils

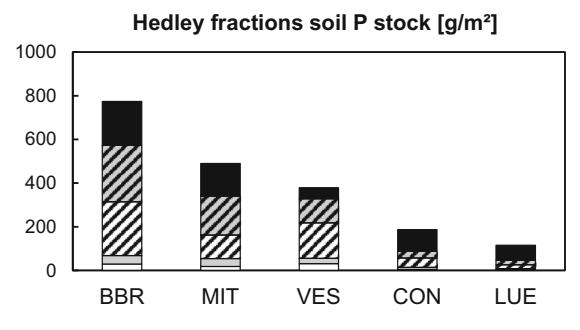

Hedley fractions soil P stock [\%]

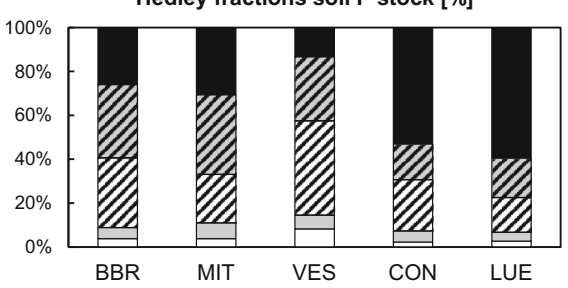

Fig. 6 Phosphorus forms quantified by ${ }^{31} \mathrm{P}-\mathrm{NMR}$ spectroscopy of soil $\mathrm{NaOH}$ EDTA extracts from O layer and mineral topsoil horizons of profiles Mangfallgebirge N1 and Tuttlingen NE (Wang et al. 2020). Left: Contents in $\mathrm{mg} \mathrm{P} \mathrm{kg}^{-1}$; bars in shaded gray represent total $\mathrm{P}$ in respective horizon. Right: Contribution of different $\mathrm{P}$ forms to total extractable $\mathrm{P}$
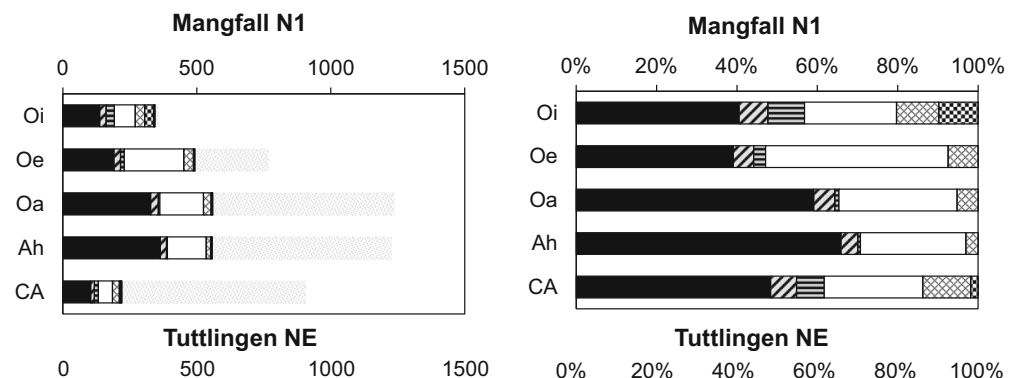

$\frac{\text { Diester P }}{\text { Monoester P }}$
0.18
0.13
0.09
0.06
0.13

0.38
0.11
0.09
0.02

目 Lipids

\& Polyphosphate (i.e. insoluble limestone dissolution residue $+\mathrm{SOM}$ ) accumulation (Fig. 1). Stocks of $\mathrm{P}$ bound in stones and grit within the profile were decreasing faster with progressing pedogenesis than fine earth $\mathrm{P}$ stocks were increasing, indicating overall ecosystem $\mathrm{P}$ losses during pedogenesis also on carbonate sites, as shown before for silicate sites (Walker and Syers 1976; Lajtha and Schlesinger 1988; Crews et al. 1995; Chen et al. 2015). In line with the concept of Walker and
Syers (1976), stocks of lithogenic Ca-bound P and the relative contribution of $\mathrm{Ca}$-bound $\mathrm{P}$ to total soil $\mathrm{P}$ decreased with progressing pedogenesis (Fig. 9b). Yet, in contrast to their study, where Ca-bound $\mathrm{P}$ was completely lost in glacier forefield moraines after 22,000 years of soil formation under cool temperate climate, at $B A E$ even after $>2.5 \mathrm{Ma}$ of pedogenesis under different (humid, cold-arid, tropical) climate regimes, limestone rock fragments and $\mathrm{Ca}$-bound $\mathrm{P}$ 

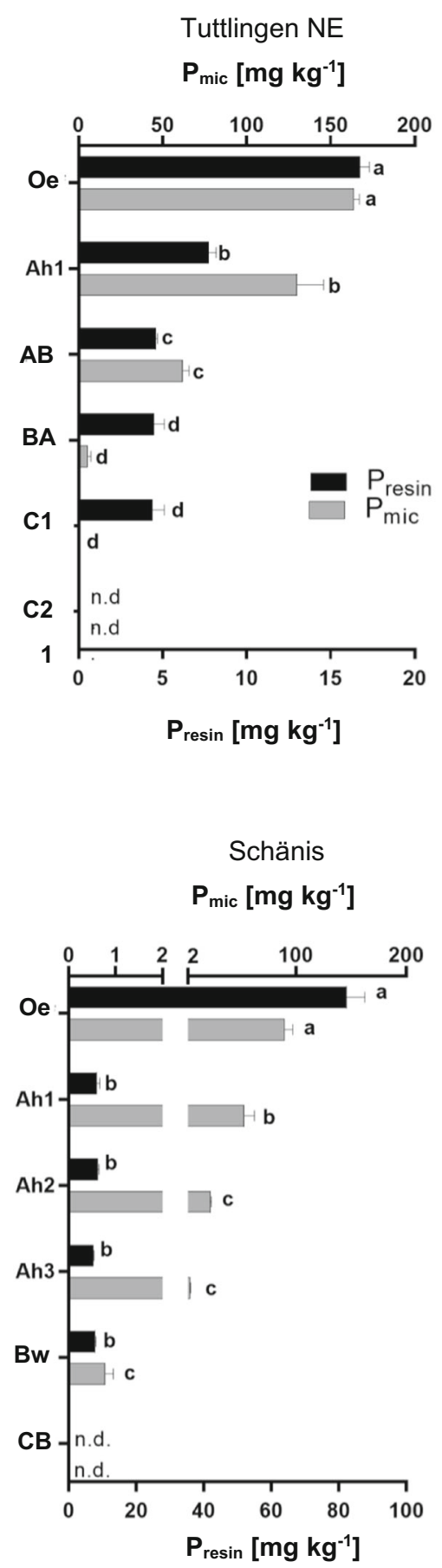

Fig. 7 Soil microbial biomass phosphorus $\left(\mathrm{P}_{\text {mic }}\right)$ and extractable $\mathrm{P}\left(\mathrm{P}_{\text {resin }}\right)$ in profiles Mangfallgebirge N1, Tuttlingen $N E$, Schänis, and Bärenthal. Significant differences $(\mathrm{p}<0.05)$

still present in the Bw horizons at $50 \mathrm{~cm}$ depth (Fig. 1; Table 1). We assume that despite its plateau position with an inclination of only $2 \% B A E$ has lost a
Mangfall N1

\section{$P_{\text {mic }}\left[\mathrm{mg} \mathrm{kg}^{-1}\right.$ ]}

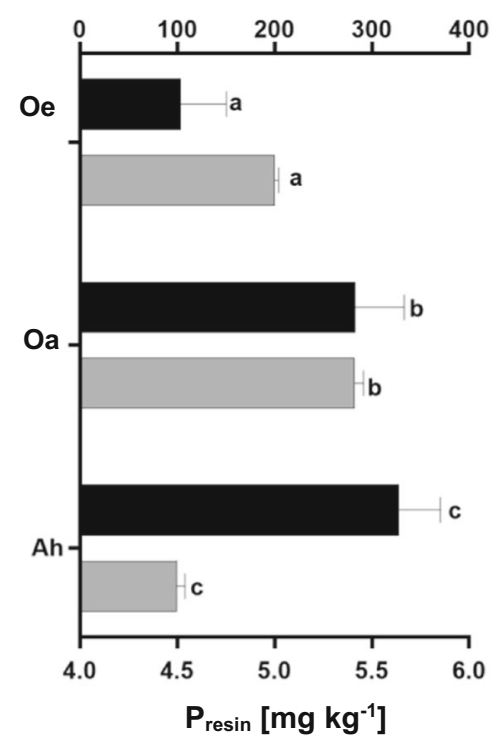

Bärenthal

$P_{\text {mic }}\left[\mathrm{mg} \mathrm{kg}^{-1}\right]$

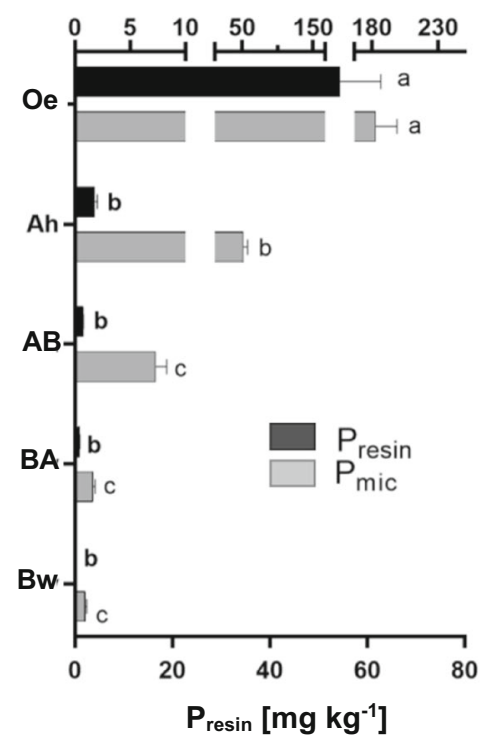

between horizons are denoted with lower-case letters. Values below detection limit are denoted with n.d

considerable portion of its pre-Pleistocene topsoil by solifluction during the Pleistocene. Forest vegetation colonizing the site in the early Holocene therefore 
Table 4 Contents of microbial $\mathrm{C}\left(\mathrm{C}_{\mathrm{mic}}\right), \mathrm{N}\left(\mathrm{N}_{\text {mic }}\right)$, and $\mathrm{P}$ $\left(\mathrm{P}_{\text {mic }}\right), \mathrm{C}_{\mathrm{mic}} / \mathrm{P}_{\text {mic }}$ and $\mathrm{C}_{\mathrm{mic}} / \mathrm{N}_{\text {mic }}$ mass ratios as well as mass ratios of organic $\mathrm{C}\left(\mathrm{C}_{\text {org }}\right)$ over organic $\mathrm{P}\left(\mathrm{P}_{\text {org }}\right)$ and organic $\mathrm{N}$
$\left(\mathrm{N}_{\text {org }}\right)$ in the Ah1 horizons of the carbonate profiles Mangfallgebirge N1, Tuttlingen NE, and Schänis

\begin{tabular}{|c|c|c|c|c|c|c|c|c|c|c|c|}
\hline Site & Method & $\begin{array}{l}\mathrm{C}_{\text {mic }} \\
(\mu \mathrm{g} \\
\mathrm{g}^{-1} \\
)\end{array}$ & $\begin{array}{l}\mathrm{N}_{m i c} \\
(\mu \mathrm{g} \\
\mathrm{g}^{-1} \\
)\end{array}$ & $\begin{array}{l}P_{m i c} \\
(\mu g \\
g^{-1} \\
)\end{array}$ & $\begin{array}{l}P_{\text {resin }} \\
(\mu g \\
g^{-1} \\
)\end{array}$ & $\begin{array}{l}\mathrm{C}_{\text {mic }} / \\
\mathrm{P}_{\text {mic }} \\
(\mathrm{g} \\
\mathrm{g}^{-1} \\
\quad)\end{array}$ & $\begin{array}{l}\mathrm{C}_{\text {mic }} / \\
\mathrm{N}_{\text {mic }} \\
(\mathrm{g} \\
\mathrm{g}^{-1} \\
)^{-1}\end{array}$ & $\begin{array}{l}\mathrm{C}_{\text {org }} / \\
\mathrm{P}_{\text {org }} \text { soil } \\
\left(\mathrm{g} \mathrm{g}^{-1}\right)\end{array}$ & $\begin{array}{l}\mathrm{C}_{\text {org }} / \\
\mathrm{N}_{\text {org }} \\
\text { soil } \\
\left(\mathrm{g} \mathrm{g}^{-1}\right)\end{array}$ & $\begin{array}{l}\text { Pmic/Cmic } \\
\mathrm{P}_{\mathrm{org}} / \mathrm{C}_{\mathrm{org}} \\
\text { (Factor of enr } \\
\text { in soil microor } \\
\text { relative to SOI }\end{array}$ & $\begin{array}{l}\frac{\mathrm{Nmic} / \mathrm{Cmic}}{\mathrm{N}_{\text {org }} / \mathrm{C}_{\mathrm{org}}} \\
\text { ichment } \\
\text { rganisms } \\
\text { M) }\end{array}$ \\
\hline \multicolumn{12}{|c|}{ Carbonate parent material } \\
\hline $\begin{array}{l}\text { Mangfallgebirge } \\
\quad \text { N1 }\end{array}$ & Resin & 2487 & 440 & 76 & 6 & 33 & 5.7 & 208 & 16.4 & 6.3 & 2.7 \\
\hline Tuttlingen NE & Resin & 1571 & 210 & 81 & 5 & 19 & 7.5 & 124 & 14.3 & 6.5 & 2.0 \\
\hline Schänis & Resin & 2955 & 570 & 58 & 8 & 51 & 5.2 & 83 & 10.2 & 1.6 & 2.0 \\
\hline
\end{tabular}

Table 5 Activities of phosphomonoesterase [MONO] and phosphodiesterase [DI] as well as phosphomono-esterase/phosphodiesterase ratios in $\mathrm{Oe}, \mathrm{Oa}$, and $\mathrm{Ah}$ horizons of the profiles on carbonate parent material (mean \pm standard deviation, $\mathrm{n}=3$ )

$\begin{array}{lll}\text { Phosphomonoesterase [MONO] (pH 5.0) } & \text { Phosphodiesterase [DI] (pH 8.0) } & \text { MONO/DI } \\ m g \text { Phenol } & m g \text {-Nitrophenol } & \text { Ratio } \\ g^{-1} \text { soil } 3 h^{-1} & g^{-1} \text { soil } 1 h^{-1} & \end{array}$

Oe horizons

Mangfallgebirge N1

Mangfallgebirge S1

Tuttlingen $\mathrm{SW}$

Tuttlingen NE

Bärenthal

Schänis

Oa horizons

Mangfallgebirge N1

Mangfallgebirge S1

Ah1 horizons

Mangfallgebirge N1

Mangfallgebirge S1

Tuttlingen SW

Tuttlingen NE

Bärenthal

Schänis

$$
\begin{aligned}
& 124.3 \pm 14.3 \\
& 37.7 \pm 15.1 \\
& 58.8 \pm 2.9 \\
& 28.8 \pm 2.7 \\
& 58.6 \pm 3.3 \\
& 48.0 \pm 3.1
\end{aligned}
$$$$
g^{-1} \text { soil } 1 h^{-1}
$$

$\begin{array}{ll}2.2 \pm 0.2 & 57 \\ 1.6 \pm 0.1 & 23 \\ 1.3 \pm 0.0 & 45 \\ 1.2 \pm 0.3 & 24 \\ 1.3 \pm 0.1 & 46 \\ 1.5 \pm 0.1 & 33\end{array}$

$53.7 \pm 0.9$

$0.76 \pm 0.03$ 71

$30.5 \pm 0.04$

$1.3 \pm 0.0$

$8.5 \pm 0.2$

$0.44 \pm 0.00$

$8.9 \pm 0.1$

$0.61 \pm 0.01$

15

$6.5 \pm 0.1$

$0.52 \pm 0.00$

12

$0.35 \pm 0.01$

$7.8 \pm 0.0$

$0.24 \pm 0.03$

$0.21 \pm 0.01$ could access and mine the underlying limestone rock, which was present at a depth $<60 \mathrm{~cm}$, well within the rooting zone of forest trees, for $\mathrm{P}$. At present, $15 \%$ of total $\mathrm{P}$ in the Ah horizon of $B A E$ is $\mathrm{Ca}$-bound $\mathrm{P}_{\text {org }}(\mathrm{Ca}-$ IHP), probably indicating steady combined input of $\mathrm{Ca}$ and $\mathrm{P}$ with litter into the acidified topsoil (Clarholm and Skyllberg 2013).
Advancing limestone weathering, pedogenesis, and topsoil acidification in our chronosequence resulted in a decrease of Ca-bound soil $\mathrm{P}$ by dissolution of inorganic and organic $\mathrm{Ca}$ phosphates as well as accumulation of Al- and Fe-rich limestone dissolution residue, including $\mathrm{Al}$ and $\mathrm{Fe}$ oxyhydroxides. Stocks of Fe-bound $\mathrm{P}$ and their contribution to total soil $\mathrm{P}$ in our limestone-derived soils reached a maximum at 
Table 6 Results of isotopic exchange analyses for the study sites Mangfallgebirge, Tuttlingen, Schänis, and Bärenthal (mean \pm standard deviation, $\mathrm{n}=3$ ). Water extractable $\mathrm{P}\left(\mathrm{P}_{\mathrm{w}}\right)$ and total inorganic $\mathrm{P}\left(\mathrm{P}_{\mathrm{i}}\right)$. Fitting parameters $(m$ and $n)$ describing the decrease of radioactivity in the solution with time, amount of $\mathrm{P}$ isotopically exchangeable within $1 \mathrm{~min}\left(\mathrm{E}_{1 \mathrm{~min}}\right)$, between $1 \mathrm{~min}$ and 1 day $\left(\mathrm{E}_{1 \mathrm{~min}-1 \text { day }}\right)$, between 1 day and 3 months ( $\left.E_{1 \text { day-3 months }}\right)$, and amount of $\mathrm{P}$ not exchangeable within 3 months ( $\mathrm{E}_{>3}$ months $)$

\begin{tabular}{|c|c|c|c|c|c|c|c|c|}
\hline & $\begin{array}{l}\mathrm{P}_{\mathrm{w}} \\
\left(\mu \mathrm{g} \mathrm{P} \mathrm{g}^{-1} \text { soil }\right)\end{array}$ & $\begin{array}{l}\mathrm{P}_{\mathrm{i}} \\
\left(\mu \mathrm{g} \mathrm{P} \mathrm{g}^{-1}\right. \\
\quad \text { soil })\end{array}$ & $\mathrm{m}$ & $\mathrm{N}$ & $\begin{array}{l}\mathrm{E}_{1 \mathrm{~min}} \\
\left(\mu \mathrm{g} \mathrm{P} \mathrm{g}^{-1}\right. \\
\text { soil) }\end{array}$ & $\begin{array}{l}\mathrm{E}_{1 \text { min-1 day }} \\
\left(\mu \mathrm{g} \mathrm{P} \mathrm{g}^{-1}\right. \\
\text { soil) }\end{array}$ & $\begin{array}{l}\mathrm{E}_{1 \text { day- }} \\
3 \text { months } \\
\left(\mu \mathrm{g} \mathrm{P} \mathrm{g} \mathrm{g}^{-1}\right. \\
\text { soil })\end{array}$ & $\begin{array}{l}\mathrm{E}_{>3} \text { months } \\
\left(\mu \mathrm{g} \mathrm{P} \mathrm{g}^{-1}\right. \\
\quad \text { soil })\end{array}$ \\
\hline \multicolumn{9}{|c|}{ Mangfallgebirge S1 } \\
\hline Ah1 & $2.97 \pm 0.86$ & 134.6 & $0.51 \pm 0.18$ & $0.59 \pm 0.03$ & $7.5 \pm 4.5$ & $93.4 \pm 11.6$ & $30.4 \pm 14.1$ & $3.3 \pm 1.9$ \\
\hline $\mathrm{Bk}$ & $0.19 \pm 0.21$ & 48.2 & $0.03 \pm 0.01$ & $0.59 \pm 0.10$ & $5.2 \pm 4.5$ & $33.8 \pm 4.7$ & $8.0 \pm 7.0$ & $1.2 \pm 1.4$ \\
\hline \multicolumn{9}{|c|}{ Mangfallgebirge $S 2$} \\
\hline $\mathrm{Ah}$ & $0.66 \pm 0.29$ & 138.9 & $0.17 \pm 0.06$ & $0.61 \pm 0.07$ & $4.4 \pm 2.6$ & $92.3 \pm 14.5$ & $37.9 \pm 13.2$ & $4.3 \pm 3.3$ \\
\hline $\mathrm{AC}$ & $0.48 \pm 0.13$ & 104.9 & $0.23 \pm 0.07$ & $0.40 \pm 0.87$ & $2.2 \pm 0.9$ & $27.2 \pm 15.7$ & $39.0 \pm 10.8$ & $36.4 \pm 24.8$ \\
\hline \multicolumn{9}{|c|}{ Tuttlingen NE } \\
\hline Ah1 & $2.42 \pm 0.22$ & 174.8 & $0.35 \pm 0.05$ & $0.33 \pm 0.01$ & $6.8 \pm 0.9$ & $45.7 \pm 5.7$ & $61.0 \pm 1.6$ & $61.3 \pm 8.1$ \\
\hline BA & $0.82 \pm 0.13$ & 103.8 & $0.19 \pm 0.01$ & $0.37 \pm 0.02$ & $4.1 \pm 0.7$ & $35.0 \pm 2.9$ & $39.9 \pm 1.7$ & $24.9 \pm 3.4$ \\
\hline $\mathrm{C} 1$ & $0.77 \pm 0.03$ & 141.9 & $0.16 \pm 0.01$ & $0.35 \pm 0.00$ & $4.7 \pm 0.2$ & $37.6 \pm 1.1$ & $52.5 \pm 0.5$ & $47.1 \pm 1.6$ \\
\hline \multicolumn{9}{|c|}{ Schänis } \\
\hline Ah1 & $1.13 \pm 0.21$ & 140.8 & $0.36 \pm 0.13$ & $0.43 \pm 0.03$ & $3.3 \pm 0.7$ & $44.0 \pm 9.8$ & $60.5 \pm 2.9$ & $33.0 \pm 12.1$ \\
\hline Ah2 & $0.13 \pm 0.07$ & 103.0 & $0.14 \pm 0.05$ & $0.46 \pm 0.07$ & $0.9 \pm 0.4$ & $20.4 \pm 11.9$ & $42.8 \pm 11.4$ & $38.9 \pm 23.5$ \\
\hline Bw1 & $0.09 \pm 0.01$ & 77.7 & $0.05 \pm 0.01$ & $0.42 \pm 0.03$ & $1.8 \pm 0.2$ & $24.3 \pm 2.8$ & $33.7 \pm 1.7$ & $18.0 \pm 4.0$ \\
\hline \multicolumn{9}{|c|}{ Bärenthal } \\
\hline $\mathrm{Ah}$ & $1.14 \pm 0.15$ & 54.0 & $0.35 \pm 0.02$ & $0.40 \pm 0.04$ & $3.2 \pm 0.4$ & $25.1 \pm 4.3$ & $18.3 \pm 1.2$ & $7.5 \pm 3.5$ \\
\hline BA & $0.05 \pm 0.03$ & 48.0 & $0.02 \pm 0.00$ & $0.40 \pm 0.03$ & $2.3 \pm 1.3$ & $19.6 \pm 7.2$ & $17.0 \pm 3.5$ & $9.0 \pm 5.1$ \\
\hline $\mathrm{Bw}$ & $0.003 \pm 0.000$ & 92.0 & $0.01 \pm 0.00$ & $0.32 \pm 0.03$ & $0.3 \pm 0.0$ & $2.7 \pm 0.4$ & $8.5 \pm 2.5$ & $80.5 \pm 2.8$ \\
\hline
\end{tabular}

intermediate stages of pedogenesis. According to the XANES results, in the old Cambisol BAE Al-bound $\mathrm{P}$ dominated over Fe-bound $\mathrm{P}$, indicating that ultimately gibbsite and kaolinite were more important for soil $\mathrm{P}$ retention and storage than goethite and hematite. Yet, the majority of soil $\mathrm{P}$ in $B A E$ was organic (Fig. 9a), and $\mathrm{P}$ K-edge XANES may have erroneously identified a considerable portion of $\mathrm{P}_{\text {org }}$ bound to $\mathrm{Fe}$ oxyhydroxides as Al-bound P (Prietzel and Klysubun 2018). Combination of the information retrieved by wet-chemical digestion, XANES, and Hedley fractionation (Fig. 9a-c) indicated that most of the $\mathrm{P}$ termed "occluded P" by Walker and Syers (1976), and "stable P" by Hedley et al. (1982) was Al- or Febound $\mathrm{P}_{\text {org. }}$. The latter was most likely occluded in, strongly adsorbed to, and/or co-precipitated with $\mathrm{Al}$ and $\mathrm{Fe}$ oxyhydroxides. Overall, pedogenesis in limestone soils has resulted in a long-term change from recycling to acquiring ecosystem $P$ nutrition (Table 7), suggesting that the small (moderately) labile $\mathrm{P}$ stock $\left(84 \mathrm{~g} \mathrm{~m}^{-2}\right)$ in the $B A E$ profile is a sufficiently large pool of ecosystem-available $\mathrm{P}$ for an acquiring $\mathrm{P}$ nutrition strategy of the beech forest at $B A E$. In summary, these results indicate that, in contrast our hypothesis (1), the concept of Walker and Syers (1976) is only partially valid for soils derived from carbonate parent material (e.g. soil $\mathrm{P}$ speciation change from Ca-bound $\mathrm{P}$ to $\mathrm{Al}-$ and $\mathrm{Fe}$-bound $\mathrm{P}$ forms with progressing pedogenesis), and must be refuted in many aspects (decrease of total soil $\mathrm{P}$, inorganic $\mathrm{P}$, and labile, plant-available $\mathrm{P}$ stocks with progressing pedogenesis).

Carbonate rock purity as key factor affecting soil $\mathrm{P}$ status and ecosystem $\mathrm{P}$ nutrition

Carbonate parent materials exist with different purity, i.e. in addition to the dominating ( $\mathrm{Ca}, \mathrm{Mg},[\mathrm{Fe}, \mathrm{Mn}]$ ) carbonates, other elements like $\mathrm{Al}, \mathrm{K}, \mathrm{Na}, \mathrm{Ca}, \mathrm{Mg}, \mathrm{Fe}$ (in accessory silicate minerals) or $\mathrm{Fe}, \mathrm{Al}, \mathrm{Mn}$ (in accessory oxyhydroxide minerals) may be admixed to or co-precipitated. A well-known example is the 


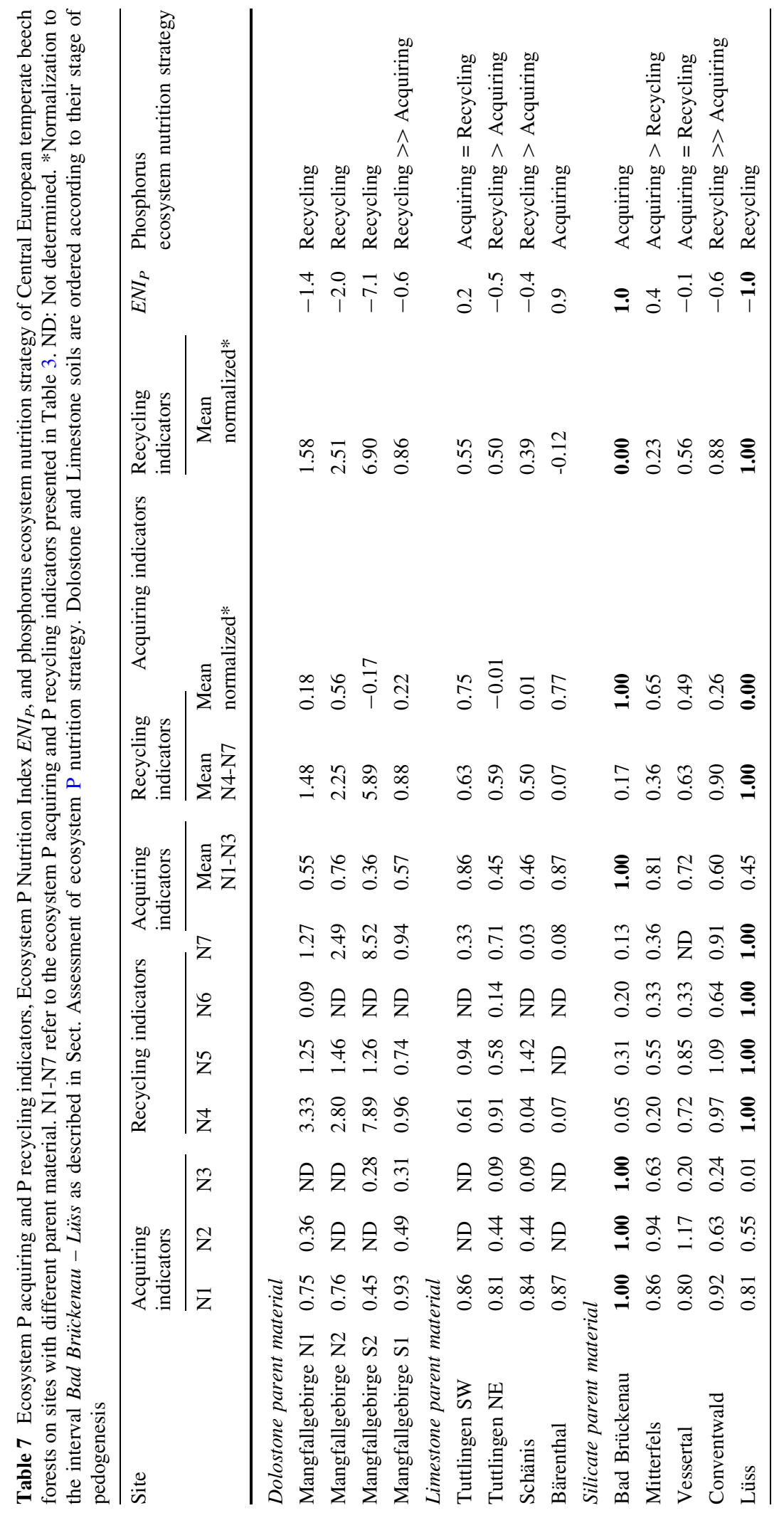



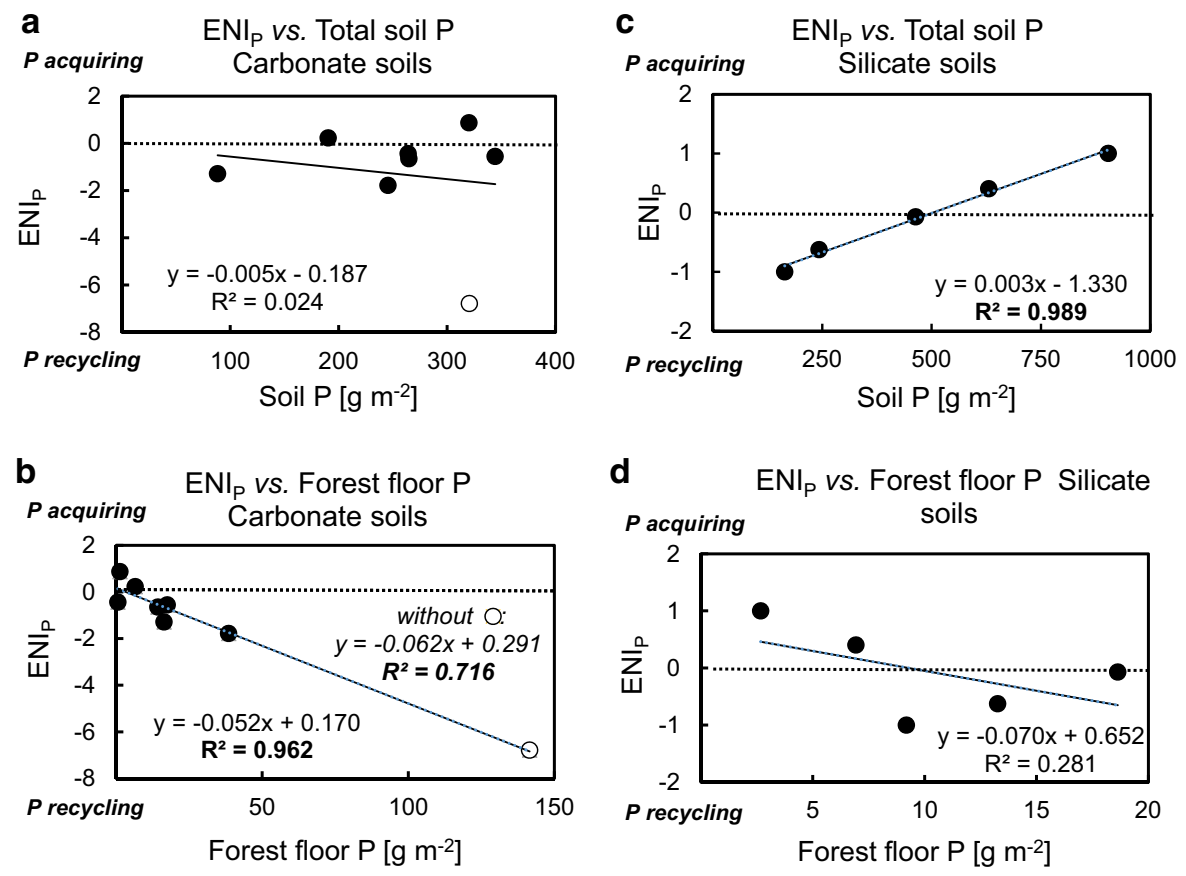

Fig. 8 Linear regression of the Ecosystem $\mathrm{P}$ Nutrition Index $\left(E N I_{P}\right) v s$. stocks of a,c total soil $\mathrm{P}$, and $\mathbf{b}, \mathbf{d}$ forest floor $\mathrm{P}$ in the carbonate soils $\mathbf{a}, \mathbf{b}$ and in the silicate soils investigated by Lang et al. (2017)
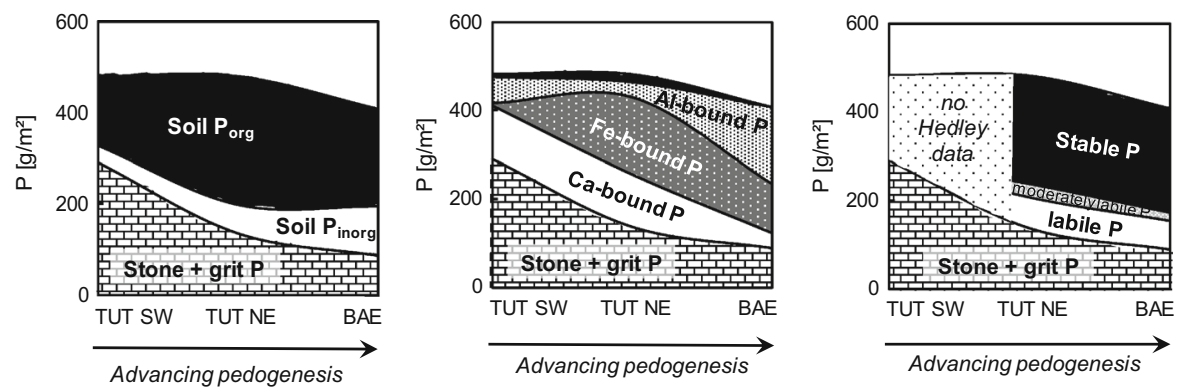

Fig. 9 Stock changes of a organic and inorganic $P, \mathbf{b}$ different $P$ forms in the mineral soil, and $\mathbf{c}$ different Hedley $\mathrm{P}$ fractions during pedogenesis of soils on limestone in the Swabian Alb (Tuttlingen region). TUT SW: Profile Tuttlingen SW (Rendzic Leptosol, age $<12,000$ years). TUT NE: Profile Tuttlingen NE,

increasing share of silicate in the sequence limestone marl limestone - marl - marl mudstone (Blatt and Tracy 1996). Moreover, P contents of carbonate parent materials vary strongly on the global scale (Porder and Ramanchandran 2013), but also on regional and local scales (Table S1). Thus, soils formed from carbonate parent material may exhibit low and high P contents, respectively (Schubert 2002). Additionally, rates of mineral weathering, accumulation of insoluble residues, and soil formation are strongly affected by
(Rendzic Leptosol with BA horizon, age $<12,000$ years. BAE: Profile Bärenthal (Cambisol, age $>2.5$ million years). P stock bound in stone and grit of TUT NE based on a bedrock P content of $150 \mathrm{mg} \mathrm{P} \mathrm{kg}^{-1}$

carbonate parent material purity. Profile $\mathrm{SCH}$ differed from the other soils by a markedly smaller parent material carbonate content of only 52\% (Table S1) compared to at least $95 \%$ in the other soils. Furthermore, the parent material $\mathrm{P}$ content at $\mathrm{SCH}$ with $275 \mu \mathrm{g} \mathrm{g}^{-1}$ was about twice as high as at the other carbonate sites (140-150 $\mu \mathrm{g} \mathrm{g}^{-1}$ ) except for TUT NE $\left(650 \mu \mathrm{g} \mathrm{g}^{-1}\right)$. At $S C H$, rapid weathering of $\mathrm{P}-$ and $\mathrm{Fe}-$ rich parent material resulted in formation of $80 \mathrm{~cm}$ thick Bw horizons (Table 1) with large stocks of SRO 
Fe minerals (ferrihydrite) within only 12,000 years. These minerals stored large $\mathrm{P}_{\text {org }}$ and $\mathrm{P}_{\text {inorg }}$ stocks (Fig. 2) by strong adsorption, occlusion, and probably also as stable ternary ferrihydrite- $\mathrm{PO}_{4}-\mathrm{Ca}$ complexes (Mendez and Hiemstra 2020). This resulted in small pools of labile P (Fig. 5), low P availability for beech trees (foliar $\mathrm{P}$ content $1.13 \mathrm{mg} \mathrm{g}^{-1}$; Table 1) and particularly for soil microorganisms $\left(\mathrm{C}_{\mathrm{mic}} / \mathrm{P}_{\text {mic }}\right.$ ratio in the Ah horizon: 51; Table 4). We therefore assume that the predominating P-recycling ecosystem nutrition strategy $\left(E N I_{\mathrm{P}}=-0.4\right.$; Table 7$)$ at $S C H$ is largely mediated by the $\mathrm{O}$ and $\mathrm{Ah}$ horizons. Also the dolostone rock at the S-exposed slope at MAN (95\% carbonate) differed from that at the $\mathrm{N}$-exposed slope (99.6\% carbonate) by a markedly larger contribution of non-carbonate compounds (Table S1): Silicon and $\mathrm{Al}$ contents were 100 times higher; $\mathrm{Fe}$ and $\mathrm{K}$ contents were 30 times higher. Yet, both parent materials had almost identical $\mathrm{P}$ contents. The increased portion of non-carbonate minerals in the parent rock of the S-exposed profiles resulted (Table 1) in elevated soil contents of total $\mathrm{Al}, \mathrm{Fe}$, and $\mathrm{K}$ as well as in advanced pedogenesis, as indicated by elevated contents of dithionite- and oxalate-extractable Fe and Al. At MAN S1, even a Cambisol with a B horizon has formed within $<12,000$ years similar to a Cambisol described by Biermayer and Rehfuess (1985) for a forest site on dolostone rock at $14 \mathrm{~km}$ distance. Moreover, and in contrast to the other dolostone sites, $\mathrm{P}$ ecosystem nutrition at MAN S1 had a P-acquiring component in addition to the dominating P-recycling $\left(E N I_{P}\right.$ : -0.6 ; other dolostone sites: $E N I_{P}:<<-1$; Table 7).

The parent material of profile TUT NE differs from that of its SW-exposed counterpart, and also from the pure $(>95 \%)$ carbonate parent materials of the other study sites by a more than four times larger $\mathrm{P}$ content (650 instead of $150 \mathrm{mg} \mathrm{P} \mathrm{kg}{ }^{-1}$; Table 1). Consequently, soil P contents (Fig. 1) and stocks (Fig. 2) in profile TUT NE were considerably larger than in TUT $S W$. The lower carbonate content in the parent rock of TUT NE compared to TUT SW was accompanied by three times larger $\mathrm{Si}, \mathrm{Al}, \mathrm{Fe}$, and $\mathrm{K}$ contents (Table S1). This resulted in accelerated pedogenesis, formation of a BA horizon, and lower $\mathrm{pH}$ values (Table 1) in TUT NE compared to TUT SW. These results demonstrate the great importance of the parent material $\mathrm{P}$ content for the soil $\mathrm{P}$ status on carbonate sites.
Comparison of sites with carbonate vs. silicate parent material

\section{Soil P status (detailed version in Supplementary Information)}

(1) Soil P stocks: Total P stocks of the carbonate soils were at the level of the P-poor soils on silicate parent materials (Fig. 2). This can be partly attributed to the low $\mathrm{P}$ content of carbonate parent materials, particularly those of high purity, compared to most silicate parent materials (Porder and Ramanchandran 2013). Moreover, chemical weathering of carbonate parent material proceeds much slower than silicate weathering, resulting in low lithogenic $\mathrm{P}$ input and low soil accumulation rates of P-retaining sesquioxides and clay minerals. A large part of the $\mathrm{P}$ stock in the carbonate forest soils was bound in forest floor SOM. This finding emphasizes the importance of $\mathrm{O}$ layer conservation for ecosystem P supply (Ewald 2000; 2005; Prietzel and Ammer 2008; Mellert and Ewald 2014). The relevance of the forest floor to soil $P$ storage and ecosystem $\mathrm{P}$ nutrition at carbonate sites decreases with progressing pedogenesis and accumulation of mineral soil material. However, in Central Europe, the Pleistocene glaciations, with few local exceptions, were associated with either complete removal of pre-Pleistocene soils, followed by a reset of pedogenesis in the Holocene, or their conversion into mixed carbonate-silicate soils by (peri)glacial admixing of allochthonous parent materials (e.g. loess, till). Thus, mature soils that have formed solely by dissolution of carbonate bedrock and accumulation of non-carbonate residue, such as the $B A E$ Cambisol, are extremely rare in Central Europe.

(2) Soil P speciation: In the carbonate-derived soils, a larger portion of total $\mathrm{P}$ than in the silicate-derived soils is Ca-bound organic P (Fig. 2). This is probably largely caused by impeded enzymatic cleavage of Ca$\mathrm{P}_{\text {org }}$ precipitates (mostly inositol hexaphosphate [IHP] monoesters; Fig. 6; Turner et al. 2002; Wang et al. 2020). Consequently, diester-P/monoester-P ratios were strongly decreased in the carbonate compared to the silicate soils. In summary, our results generally support hypothesis (2) that beech forest soils formed from carbonate rocks differ from those formed from silicate parent material regarding $\mathrm{P}$ stocks and $\mathrm{P}$ speciation. In general, $\mathrm{P}$ stocks of carbonate soils are lower than those of silicate soils, and the dominant $\mathrm{P}$ 
species comprise $\mathrm{P}_{\text {org }}$-Ca associations and a high share of monoester-P, while in silicate soils diester-P and $\mathrm{P}_{\mathrm{org}}-\mathrm{Fe} / \mathrm{Al}$ associations are of larger relevance.

(3) Plant and ecosystem P availability: Low beech foliage $\mathrm{P}$ contents (Table 1) indicate poor ecosystem $\mathrm{P}$ availability at all carbonate sites. Moreover, stocks of plant-available $\mathrm{oPO}_{4}$ and $\mathrm{C}_{\text {mic }} / \mathrm{P}_{\text {mic }}$ ratios in the carbonate soils were at the level of the P-poorest silicate soils $C O N$ and $L U E$ (Fig. 5, Figure S1, Table 4, Table S5). Furthermore, phosphorus enrichment in microbial biomass relative to SOM was much lower in the carbonate than in the silicate soils (Table 4, Table S5). The poor ecosystem $\mathrm{P}$ availability of sites with initial carbonate soils is probably caused by strong $\mathrm{P}$ incorporation in sparsely soluble $\mathrm{Ca}-\mathrm{P}_{\text {org }}$ precipitates. Ca-bound inositol phosphate is a hardly available P-bearing substrate for microorganisms and plants, resulting in P-rich SOM and large soil $\mathrm{P}_{\text {org }}$ stocks, whereas at the same time the $\mathrm{P}$ supply of soil microorganisms and trees is low.

\section{Ecosystem P nutrition strategies of beech forests on carbonate vs. silicate sites}

Insufficient $\mathrm{P}$ nutrition is a critical factor for growth and vitality of forests on carbonate soils (Ewald, 2000; 2005; Mellert and Ewald 2014). For P-poor silicate sites, Lang et al. (2017) showed that forest ecosystems cope with poor $\mathrm{P}$ supply by establishing particular traits of intensive ecosystem-internal $\mathrm{P}$ recycling. These traits include plant-internal P-reallocation, but also $\mathrm{P}$ recycling within the soil system, i.e. intensification of enzymatic $\mathrm{P}$ mobilization from SOM, followed by instantaneous re-uptake of mobilized $P$ in the forest floor and the mineral topsoil. Our results in general and in particular the strongly negative $E N I_{P}$ indices $(<-1.3$; Table 7) suggest that the Rendzic Leptosols on dolostone at $M A N$ were characterized by the same soil traits as at the P-poor silicate sites, i.e. pronounced ecosystem $\mathrm{P}$ recycling. The accumulation of thick forest floor layers at MAN, associated with large values of the P-recycling indicators N4 and N7, was probably caused by the cold and humid site climate (Prietzel et al. 2016c). Ecosystem P acquisition from lithogenic sources as shown for the silicate sites MIT and CON by Uhlig et al. (2020) was probably restricted at $M A N$ by low parent material $\mathrm{P}$ contents and weathering rates. Thus, at MAN forest floor degradation caused by forest disintegration due to climate warming (Prietzel et al. 2016c) or ungulate pressure (Prietzel and Ammer 2008) results in aggravated ecosystem $\mathrm{P}$ shortage and marked changes of soil microorganism communities and nutrient turnover pathways.

To date, ecosystem P nutrition data for forests on initial carbonate soils are lacking. We assume that, similar to silicate sites (Giguet-Covex et al. 2013; Prietzel et al. 2013), also the continuously recycling ecosystem P stock in Rendzic Leptosols had been acquired from lithogenic sources, i.e. by chemical rock weathering, and atmospheric sources, such as mineral dust (Küfmann 2006) and SOM (Zöttl 1965) during initial soil formation and ecosystem succession immediately after deglaciation in the early Holocene. In this context, it is important that hyphae of mycorrhiza and other fungi, but also free soil microorganisms directly access and mine stones and rocks for $\mathrm{P}$ (Hinsinger 2001; Stock et al. 2021; Pastore et al. 2022). However, as described in Sect. Soil P status (detailed version in Supplementary Information), soil $\mathrm{P}$ input rates by chemical and biological mineral weathering at sites on P-poor carbonate parent material probably are much lower than those at sites on silicate parent material with higher $\mathrm{P}$ contents. Thus, it can be assumed that forest ecosystems on initial carbonate soils (similar to those developing on P-poor, quartz-rich silicate parent material) shift from a P-acquiring into a P-recycling nutrition strategy as soon as reasonable amounts of P-containing SOM have been accumulated. In contrast, forests on P-rich silicate parent material may rely for longer time on the P-acquiring nutrition strategy. The systematic change from a predominantly P-acquiring to a predominantly P-recycling nutrition strategy along the geosequence $B B R\left(E N I_{P}: 1.0\right) /$ MIT (0.4) / VES (-0.1) / CON (-0.6) / LUE (-1.0) (Table 7) with decreasing substrate $\mathrm{P}$ content (Lang et al., 2017) and soil P stocks (Fig. 8c) may reflect a snapshot taken 12,000 years after onset of soil formation and forest ecosystem succession (Fig. 10). The transformation from initially $\mathrm{P}$-acquiring to ultimately P-recycling nutrition depicted in Fig. 10 is probably caused by accumulation of P-bearing SOM in the forest floor and the mineral topsoil and concomitant gradual replacement of bedrock by P-depleted silicate weathering products (the nonSOM mineral soil fraction) during pedogenesis. Fine earth $\mathrm{P}$ contents in the $\mathrm{Bw}$ horizons of the profiles $B B R, M I T, V E S, C O N$, and LUE 12,000 years after 


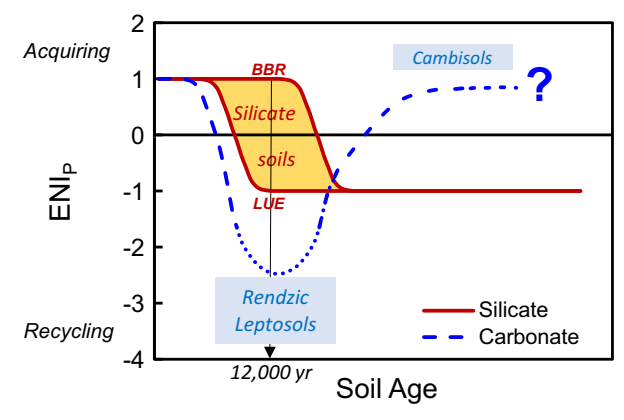

Fig. 10 Conceptual model describing ecosystem $\mathrm{P}$ nutrition strategy changes of temperate forests on soils formed from carbonate $v s$. silicate bedrock with advancing pedogenesis. $E N I_{P}$ : Ecosystem P Nutrition Index. BBR: Bad Brückenau, LUE: Lüss

onset of pedogenesis were $2.0,0.9,1.0,0.4$, and $0.2 \mathrm{mg} \mathrm{P} \mathrm{g}^{-1}$, respectively (Lang et al. 2017), which is only $71 \%$, (exception MIT 141\%), 43\%, 48\%, and $50 \%$ of the $\mathrm{P}$ contents in the respective parent materials (Table S1). The $\mathrm{P}$ depletion of the silicate subsoils was probably mainly caused by root $\mathrm{P}$ uptake, i.e. the initially dominating $\mathrm{P}$-acquiring ecosystem nutrition at all silicate sites.

According to their markedly negative $E N I_{P} \mathrm{~s}$, ecosystem $\mathrm{P}$ nutrition at all dolostone sites and the limestone site TUT NE was dominated by P recycling rather than $\mathrm{P}$ acquisition, and a high relevance of soil $\mathrm{P}_{\text {org }}$ turnover for ecosystem $\mathrm{P}$ nutrition, similar to the P-poor silicate sites $C O N$ and $L U E$, thus supporting hypothesis (2). Yet, we assume that the major pathways of $\mathrm{P}$ recycling differ between silicate and carbonate soils at early stages of pedogenesis. At $\mathrm{P}$-poor silicate sites, the prevailing ecosystem $\mathrm{P}$ nutrition strategy is characterized by direct biotic recycling of SOM-bound $\mathrm{P}_{\text {org }}$, which probably is mainly exerted via enzymatic cleavage of $\mathrm{SOM}-\mathrm{PO}_{4}$ bonds and subsequent uptake of the released $\mathrm{OPO}_{4}$ by plant roots, mycorrhiza fungi, and soil microorganisms. In contrast, recycling pathways of SOM-bound P in carbonate soils at early stages of pedogenesis have to include the dissolution of stable Ca- $\mathrm{P}_{\text {org }}$ (mostly CaIHP) precipitates and/or mobilization of calcite-adsorbed IHP (Celi et al. 2000) that had been formed from IHP released during SOM decomposition. Likely because of the continuous re-supply of $\mathrm{Ca}^{2+}$ from weathering rock, and unlike at the silicate sites, $\mathrm{Ca}$ $\mathrm{P}_{\text {org }}$ compounds accumulate and constitute the majority of soil $\mathrm{P}$ in carbonate soils with an early stage of pedogenesis (Fig. 2). The forest ecosystems on the Cambisols MAN SI and $\mathrm{SCH}$ according to our results were also characterized by a predominantly recycling $\mathrm{P}$ nutrition strategy. However, $E N I_{P} \mathrm{~S}$ of -0.6 and -0.4 , respectively (Table 7) indicate that $\mathrm{P}$-acquiring processes, including microbial (Pastore et al. 2022) and plant uptake of rock and subsoil $\mathrm{P}$ at these sites to some extent contribute to ecosystem $\mathrm{P}$ nutrition, similar to the silicate site $\operatorname{CON}\left(E N I_{P}-0.6\right.$; Table 7 ; Rodionov et al. 2020; Uhlig et al. 2020). It thus can be assumed, in a quantitative sense, that ecosystem $\mathrm{P}$ acquisition from lithogenic sources by plants and microorganisms is less effective in soils on P-poor carbonate bedrock (e.g. MAN; rock $\mathrm{P}$ content $150 \mathrm{mg} \mathrm{kg}{ }^{-1}$ ) compared to most soils on silicate parent materials, which are richer in P (Table S1).

Intriguingly, site $B A E$ with the oldest, pedogenetically most advanced soil in our study (Cambisol with an age $>2.5 \mathrm{Ma}$ ) showed the most positive $\operatorname{ENI}_{P}(0.9)$ of all carbonate sites, indicating a predominating $\mathrm{P}$-acquiring ecosystem nutrition strategy. In contrast to silicate sites, forest ecosystem $\mathrm{P}$ nutrition on sites with carbonate rock with progressing pedogenesis does obviously not shift systematically from an initial $\mathrm{P}$-acquiring to a P-recycling strategy. Instead, it seems to reverse to a P-acquiring strategy in the "Cambisol phase" after a dominating P-recycling strategy in the previous "Rendzic Leptosol phase". Of course, the representativeness of our result obtained for $B A E$ has to be tested by future investigation of other old Cambisols formed from carbonate rock. Yet, the proposed ecosystem reversal from a predominantly P-recycling to a predominantly $\mathrm{P}$-acquiring nutrition strategy on Cambisols formed from carbonate parent material, which is absent for Cambisols formed from silicate parent material, can be reasonably explained by the different processes responsible for Bw horizon formation in the respective Cambisols. As reported above, at silicate sites, a key pedogenetic process in the formation of Cambisols with $\mathrm{Bw}$ horizons is gradual replacement of P-rich silicate rock material by P-poorer silicate weathering products (Fig. 11, lower panels). This $\mathrm{P}$ depletion is probably mainly caused by selective apatite dissolution and $\mathrm{P}$ mining by soil microorganisms, mycorrhiza fungi, and plant roots, followed by biological $\mathrm{P}$ uplift, incorporation of the mobilized $\mathrm{P}$ in biomass including partial $\mathrm{P}$ removal from the soil, $\mathrm{P}$ enrichment and $\mathrm{P}$ recycling in the $\mathrm{Ah}$ 

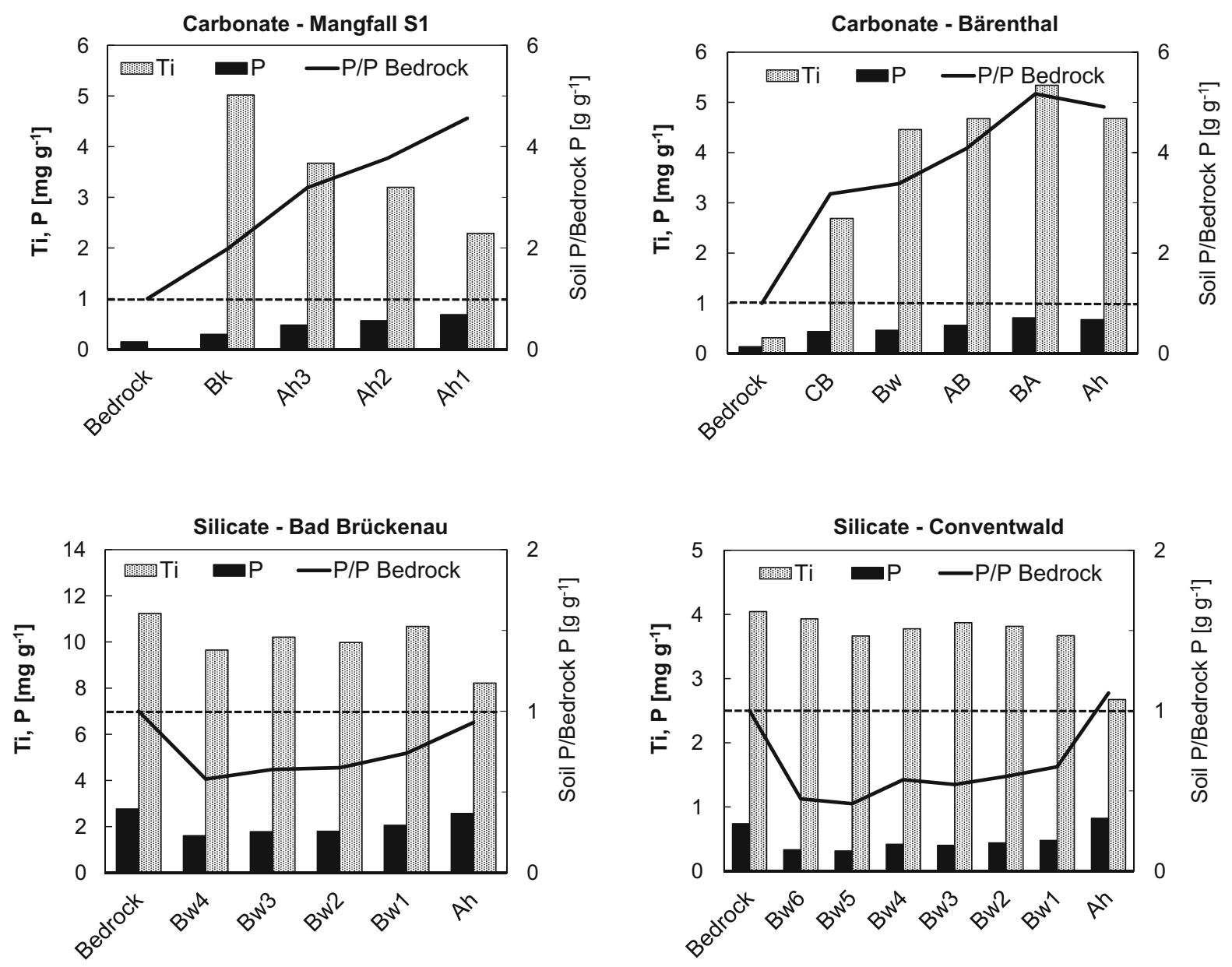

Fig. 11 Contents of titanium (Ti, index element for chemical weathering intensity) and phosphorus (P) (left axis) and ratio of soil $\mathrm{P} /$ bedrock $\mathrm{P}$ (right axis) in different soil horizons of Cambisols formed on carbonate bedrock (Mangfall Mts. N1,

horizon, and to some extent also P losses with the seepage water (Sohrt et al. 2017).

In contrast, in the Cambisols MAN S1 and BAE, the carbonate rock dissolution residue which accumulates in the B horizons in the course of pedogenesis is not depleted, but enriched in $\mathrm{P}$ compared to the initial carbonate bedrock (Fig. 11, upper panels). Fine earth $\mathrm{P}$ contents in the $\mathrm{B}$ horizons of Cambisols MAN S1 and $B A E$ were 0.4 and $0.5 \mathrm{mg} \mathrm{P} \mathrm{g}^{-1}$ (Table 2), indicating a $\mathrm{P}$ enrichment by factor 3 (BAE) (Fig. 11) compared to the respective parent materials (P content $0.15 \mathrm{mg} \mathrm{g}^{-1}$; Table $\mathrm{S} 1$ ). This $\mathrm{P}$ enrichment is mainly caused by the circumstance that in contrast to silicate weathering, during weathering of pure carbonate rock in the course of Cambisol formation the vastly

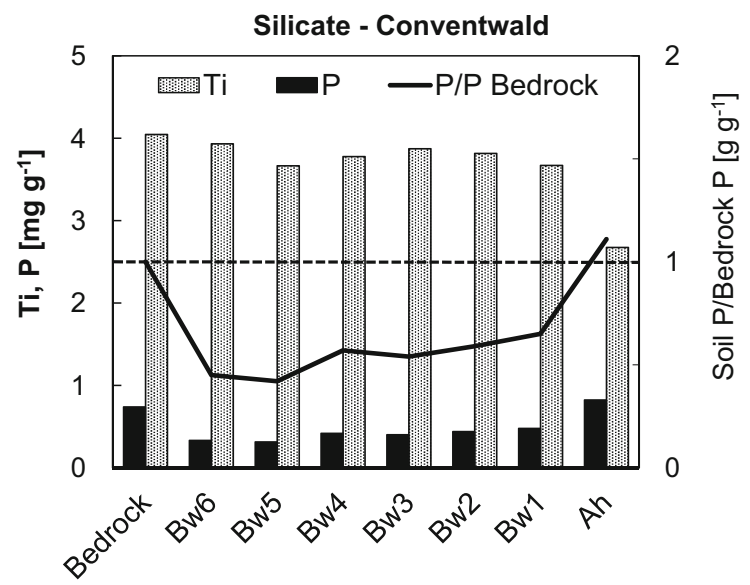

Bärenthal; upper panels) and silicate bedrock (Bad Brückenau, Conventwald; lower panels). Dashed line indicates 1:1 ratio of soil $\mathrm{P}$ to bedrock $\mathrm{P}$

dominating portion of the original rock mass leaves the soil as mobile $\mathrm{Ca}^{2+},\left(\mathrm{Mg}^{2+}\right)$, and $\mathrm{HCO}_{3}{ }^{-}$with the seepage water. Soil $\mathrm{P} /$ rock $\mathrm{P}$ content ratios greater than 1 (Fig. 11) prove that lithogenic $\mathrm{P}$ (in the carbonate rock mostly present as finely dispersed apatite) which is mobilized in the course of carbonate dissolution, is significantly retained in the carbonate dissolution residue ( $\mathrm{Al}$ and $\mathrm{Fe}$ oxyhydroxides, clay minerals, fine quartz fragments). Phosphorus thus becomes enriched in the weathering residue (rather than depleted as in the silicate soils) compared to the parent material.

$\mathrm{TiO}_{2}$ minerals (in soils mostly rutile) are very resistant to chemical weathering, and with progressive chemical weathering of rocks and soils $\mathrm{TiO}_{2}$ (and $\mathrm{Ti}$ ) 
contents increase due to selective enrichment of these minerals (Milnes and Fitzpatrick 1989; Gupta and Rao 2001). The Ti content in different soil horizons can be used as index of past chemical weathering associated with losses of elements bound in less stable minerals (Sudom and Arnaud 1971; Milnes and Fitzpatrick 1989). Strongly increased $\mathrm{Ti}$ contents in the B horizons of the carbonate soils compared to the underlying rock (Fig. 11) indicate considerable historic losses of $\mathrm{Ca}, \mathrm{Mg}$, and carbonate during weathering and soil formation. Furthermore, increased P/Ti and $\mathrm{P} / \mathrm{Fe}$ mass ratios in the $\mathrm{Ah}$ horizons of the carbonate soils compared to their respective subsoils (Fig. 11, Figure S4) suggest that plant P uplift leads to additional $\mathrm{P}$ topsoil enrichment. Balance calculations (explained in detail in the Supplementary Information) indicate that this phase is associated with ecosystem $\mathrm{P}$ leakiness and considerable $\mathrm{P}$ ecosystem losses - at least on a time scale of centuries or millennia. One important pathway in this context is $\mathrm{P}$ seepage water export. Thus, for a beech forest site with Rendzic Leptosols formed from dolostone in Northern Bavaria, Kaiser et al. (2003) reported an annual export of $40 \mathrm{mg}$ $\mathrm{P} \mathrm{m}^{-2}$ with the subsoil seepage water. This $\mathrm{P}$ export may add up to a total ecosystem loss of $400 \mathrm{~g} \mathrm{P} \mathrm{m}^{-2}$ during 10,000 years of Holocene soil formation, which is more than the total soil $\mathrm{P}$ stock in any carbonate soil in our study. Another important pathway of long-term ecosystem $\mathrm{P}$ losses is probably topsoil erosion (Alewell et al. 2020). All carbonate soils in our study, including the Cambisols, are characterized by considerable historical (BAE) and/ or recent (top)soil erosion. According to its soil mineral composition (Stahr and Böcker 2014), BAE has largely developed in the Neogene ("Tertiary"), and presumably has lost part of its topsoil material by solifluction in the Pleistocene.

Very likely, the Bw horizon was thicker at the transition Neogene-Pleistocene than today. The entire time of pedogenesis considered, the average rate of soil formation by rock weathering, including complete dissolution of its carbonate fraction, both at MANSI as well as at $B A E$ was higher than topsoil material losses by erosion; otherwise, in both profiles no Bw horizons would be present at all. During Bw horizon formation associated with pedogenetic transformation of a Rendzic Leptosol into a Cambisol, P is slowly (because of the low bedrock P content), but steadily released from the weathering carbonate rock into a new-formed deepest $\mathrm{Bw}$ horizon section. As explained before, the forest stands at MAN S1 and BAE during the Rendzic Leptosol stadium probably were strongly P-limited. Forest $\mathrm{P}$ nutrition depended on the recycling of $\mathrm{P}$ that had been acquired by the ecosystem during previous phases of soil formation, and then was stored and recycled in topsoil or forest floor SOM, litter, and plants as well as microbial biomass. At the same time, carbonate dissolution residue with high $\mathrm{P}$ content ( $3 \mathrm{mg} \mathrm{g}^{-1} \mathrm{P}$, exceeding even the $\mathrm{P}$ content of the basalt at the P-richest silicate site $B B R$; cf. calculation in Supplementary Information) was produced continuously at the boundary layer between the deepest $\mathrm{Bw}$ horizon and the carbonate bedrock ("weathering front").

The $\mathrm{P}$ in the carbonate dissolution residue was most likely bound as Ca phosphate (Hinsinger 2001) and/or as ternary $\mathrm{Fe}$ oxyhydroxide- $\mathrm{PO}_{4}-\mathrm{Ca}$ complexes (Mendez and Hiemstra 2020). At more advanced stages of pedogenesis, soil $\mathrm{pH}$ also in the $\mathrm{Bw}$ horizon decreases to values below 6 , and soil solution $\mathrm{Ca}^{2+}$ concentrations also decrease. Both processes result in $\mathrm{P}$ mobilization from secondary $\mathrm{Ca}-\mathrm{PO}_{4}$ and $\mathrm{Ca}$ phytate precipitates (Hinsinger 2001) as well as remobilization of formerly adsorbed inorganic and organic $\mathrm{P}$ from dissolving carbonates (Celi et al.2000). Thus, in contrast to the Rendzic Leptosol stage of pedogenesis and ecosystem succession, during the Cambisol formation stage of pedogenesis, a large portion of the $\mathrm{P}$ that had been released into the soil during previous rock weathering becomes bio-available and probably is rapidly being acquired by plant roots and mycorrhiza fungi. At this stage, forest ecosystems on Cambisols formed from carbonate rock probably gradually (re-)change from a P-recycling into a P-acquiring system (Fig. 10). The additional P injected into the ecosystem $\mathrm{P}$ cycle by remobilization of inositol phosphate that had been precipitated as $\mathrm{Ca}$ phytate and/or adsorbed to carbonate surfaces in the Rendzic Leptosol stage of soil formation with advancing soil acidification probably markedly increases ecosystem $\mathrm{P}$ supply and productivity. Thus, with progressing pedogenesis, forests on carbonate parent material are turning into "pseudo-silicate" systems with (temporarily) high P supply and predominance of $\mathrm{P}$-acquiring ecosystem nutrition. This situation is represented by site $B A E$, whose $E N I_{P}$ with 0.9 (Table 7) is almost as high as that of the P-richest silicate site $B B R$ (1.0). However, plant root $\mathrm{P}$ 
acquisition from the $\mathrm{Bw}$ horizon, subsequent plant $\mathrm{P}$ uplift, and ultimate deposition of that $\mathrm{P}$ on and in the topsoil by litterfall and rhizodeposition result in gradual $\mathrm{P}$ depletion, and, thus, $\mathrm{P}$ content decrease of the Bw horizon. Simultaneously, with increasing ecosystem $\mathrm{P}$ supply $\mathrm{P}$ (re)cycling is becoming less tight, and the ecosystem becomes increasingly "leaky" with respect to P. As mentioned before, a major pathway of ecosystem $\mathrm{P}$ losses apart from erosion is probably $\mathrm{P}$ export with the soil seepage water, particularly as DOP and/or colloid-bound $\mathrm{P}$ rather than $\mathrm{OPO}_{4}$ (Kaiser et al. 2003; Wang et al. 2020). At the high-elevation site $M A N$ with its steep mountain slopes, additionally plant litter and topsoil erosion, probably associated with snow gliding events (Prietzel 2010) contribute to ecosystem P losses. These $\mathrm{P}$ losses are continuously replaced by plant $\mathrm{P}$ acquisition in the $\mathrm{Bw}$ horizon, plant $\mathrm{P}$ uplift, and topsoil deposition of litter $\mathrm{P}$, as long as subsoil $\mathrm{P}$ is available and rates of soil $(\mathrm{Bw})$ formation and soil $\mathrm{P}$ input at the weathering front compensating are same or higher than (top)soil material and $\mathrm{P}$ losses. The positive ecosystem $\mathrm{P}$ balance at this stage of soil development results in a favorable ecosystem $\mathrm{P}$ nutrition status. This is consistent with reports that temperate forests on deep Cambisols formed from carbonate rock generally show good or excellent stand P nutrition (Rehfuess 1990).

In the long run, the positive material balance in developing Cambisols on carbonate rock (i.e. the balance of new formation of $\mathrm{Bw}$ material at the weathering front in the subsoil minus topsoil losses by erosion) will result in a continuously increasing thickness of the Bw horizon. Then the boundary layer, where P-poor carbonate rock weathers and leaves behind $\mathrm{P}$-rich $\mathrm{Bw}$ material will gradually move further down both in absolute terms as well as relative to the soil surface. At some point in time, plant roots may hardly reach it. Ecosystem acquisition of lithogenic $\mathrm{P}$ then may become increasingly difficult. At this stage, continuous ecosystem $\mathrm{P}$ losses will be associated with progressive $\mathrm{P}$ depletion of the rooted soil, with the remaining $\mathrm{P}$ bound to soil $\mathrm{Fe}$ and $\mathrm{Al}$ oxyhydroxides being increasingly less available to plants and soil microorganisms. At this time, ecosystem P supply will deteriorate again, and the system will probably eventually return into P-recycling mode. The ultimate fate of forest ecosystems on soils formed from carbonate bedrock in terms of ecosystem $\mathrm{P}$ nutrition thus will be similar to that of forest ecosystems on silicate parent material.

We are aware that the carbonate sites in our study do not represent true chronosequences, and that the presented $E N I_{p}$ concept is a ranking tool rather than allowing for quantitative assessment of ecosystem $\mathrm{P}$ nutrition (see detailed discussion in the Supplementary Information). Nevertheless, the novel information gathered from our study indicates the validity of our hypothesis (3) that the concept of P-acquiring $v s$. P-recycling ecosystems developed for temperate forests at silicate sites by Lang et al. $(2016 ; 2017)$ is also applicable for carbonate sites. Moreover, it led to the development of a conceptual model describing and comparing the change in forest ecosystem $\mathrm{P}$ nutrition strategies (i.e. the $E N I_{p}$ ) on soils formed from calcareous $v s$. silicate parent material with time and progressing pedogenesis. Our model (Fig. 10) complements the fundamental models describing and explaining soil $\mathrm{P}$ and forest ecosystem change on sites with silicate parent material developed by Walker and Syers (1976), Wardle et al. (2004), and Turner et al. (2007; 2013). A novel key feature of our conceptual model is the presence of a second period of $\mathrm{P}$-acquiring ecosystem nutrition in Cambisols formed from carbonate bedrock after an initial phase of dominating P-recycling nutrition when soils are less developed (Rendzic Leptosols). Even if our model may be modified or even refuted in future studies, our study for the first time presents detailed information of soil $\mathrm{P}$ and forest ecosystem changes on sites with carbonate parent material, which support large forest areas.

\section{Conclusions}

The $\mathrm{P}$ status of temperate forest soils on carbonate parent material at early stages of pedogenesis (Rendzic Leptosols) is characterized by low P stocks and a large fraction of $\mathrm{Ca}$-bound $\mathrm{P}_{\text {org }}$. At sites with such soils, the $\mathrm{P}$ nutrition of beech forests largely depends on tight (re)cycling of $\mathrm{P}$ within the forest floor SOM. This highlights the importance of forest floor conservation for ecosystem $\mathrm{P}$ nutrition at these sites. Recycling pathways of SOM-bound $\mathrm{P}$ in carbonate soils at early stages of pedogenesis and high $\mathrm{Ca}$ abundance in the entire profile have to include the dissolution of stable $\mathrm{Ca}-\mathrm{P}_{\text {org }}$ precipitates, which are 
formed during SOM decomposition and constitute the majority of soil $\mathrm{P}$. With progressing pedogenesis of carbonate soils and formation of $\mathrm{Bw}$ horizons, soil $\mathrm{P}$ stocks increase. This is due to the formation of Ca-P complexes as well as due to the formation of inorganic $\mathrm{P}$ and $\mathrm{Al}-$ or Fe-bound $\mathrm{P}$ pools, when silicate and Fe oxyhydroxide admixtures in the carbonate parent materials help retain $\mathrm{P}$ while more mobile elements become dissolved and lost. Forest $\mathrm{P}$ nutrition strategies then return to a second phase of predominately P-acquiring nutrition strategy as it had been at the very onset of soil formation and ecosystem succession. At this stage of ecosystem development, and in contrast to silicate sites, soil acidification and progressing pedogenesis support improved soil $\mathrm{P}$ status rather than deteriorating it. Using the novel Ecosystem Phosphorus Nutrition Index $\left(E N I_{P}\right)$ allows for assessing the relative contribution of $\mathrm{P}$-acquiring and $\mathrm{P}$-recycling processes for forest ecosystem $\mathrm{P}$ nutrition. It proved useful for comprehensive ranking of beech forests on different silicate or carbonate parent materials regarding their ecosystem $\mathrm{P}$ nutrition strategy.

Acknowledgements The authors thank the participating German and Swiss Forest Service Authorities for supporting our research, and our technicians, master, and bachelor students, as well as student helpers for their valuable contributions.

Funding Open Access funding enabled and organized by Projekt DEAL. This project was conducted in the framework of the priority programme 1685 "Ecosystem Nutrition: Forest Strategies for limited Phosphorus Resources" funded by the German Research Foundation (DFG) (projects LA 1398/13, AM 134/18, BA 2821-13, KA 1590/12, KA 1673/9, PR 534/6, SI 1106/8-2, DI 2136/6, KU 1184/38-2) in cooperation with the Swiss National Foundation (SNF) (projects 200021E-171170/ 171172, SS 200021E-171173).

Data availability The data will be made available on request.

Code availability Not applicable.

\section{Declarations}

Conflict of interest The authors have no conflicts of interest to declare that are relevant to the content of this article.

Open Access This article is licensed under a Creative Commons Attribution 4.0 International License, which permits use, sharing, adaptation, distribution and reproduction in any medium or format, as long as you give appropriate credit to the original author(s) and the source, provide a link to the Creative Commons licence, and indicate if changes were made. The images or other third party material in this article are included in the article's Creative Commons licence, unless indicated otherwise in a credit line to the material. If material is not included in the article's Creative Commons licence and your intended use is not permitted by statutory regulation or exceeds the permitted use, you will need to obtain permission directly from the copyright holder. To view a copy of this licence, visit http://creativecommons.org/licenses/by/4.0/.

\section{References}

Alewell C, Ringeval B, Ballabio C et al (2020) Global phosphorus shortage will be aggravated by soil erosion. Nat Commun 11:4546. https://doi.org/10.1038/s41467-02018326-7

Amelung W, Rodionov A, Urusevskaja I et al (2001) Forms of organic phosphorus in zonal steppe soils of Russia assessed by ${ }^{31} \mathrm{P}$ NMR. Geoderma 103(3-4):335-350. https://doi. org/10.1016/S0016-7061(01)00047-7

Baier R, Ettl R, Hahn C et al (2006) Early development and nutrition of Norway spruce (Picea abies [L.] Karst) seedlings on mineral soil, organic layer, and decayed woody debris origin from dolomite sites of the Bavarian limestone Alps - a bioassay. Ann for Sci 63:339-348. https://doi.org/ 10.1051/forest:2006014

Bardgett RD, Hobbs PJ, Frostegård A (1996) Changes in soil fungal:bacterial biomass ratios following reductions in the intensity of management of an upland grassland. Biol Fertil Soils 22:261-264. https://doi.org/10.1007/BF00382522

Biermayer G, Rehfuess KE (1985) Holozäne Terrae fuscae aus carbonatgesteinen in den Nördlichen Kalkalpen. Z Pflanzenern Bodenkde 148:405-416. https://doi.org/10. 1002/jpln.19851480405

Blatt H, Tracy RJ (1996) Petrology: igneous, sedimentary, and metamorphic, 2nd edn. WH Freeman, New York

Bligh EG, Dyer WJ (1959) A rapid method of total lipid extraction and purification. Can $\mathrm{J}$ Biochem Physiol 37:911-917. https://doi.org/10.1139/y59-099

Bol R, Amelung W, Haumaier L (2006) Phosphorus-31-nuclear magnetic-resonance spectroscopy to trace organic dung phosphorus in a temperate grassland soil. J Plant Nutr Soil Sci 169(1):69-75. https://doi.org/10.1002/jpln.20052177

Brookes PC, Landman A, Pruden G, Jenkinson DS (1985) Chloroform fumigation and the release of soil nitrogen: a rapid direct extraction method to measure microbial biomass nitrogen in soil. Soil Biol Biochem 17(6):837-842. https://doi.org/10.1016/0038-0717(85)90144-0

Bruulsema TW, Duxbury JM (1996) Simultaneous measurement of soil microbial nitrogen, carbon, and carbon isotope ratio. Soil Sci Soc Am J 60(6):1787-1791

Bünemann EK, Bossio DA, Smithson PC et al (2004) Microbial community composition and substrate use in a highly weathered soil as affected by crop rotation and P fertilization. Soil Biol Biochem 36(6):889-901. https://doi.org/ 10.1016/j.soilbio.2004.02.002

Bünemann EK, Augstburger S, Frossard E (2016) Dominance of either physicochemical or biological phosphorus cycling processes in temperate forest soils of contrasting phosphate 
availability. Soil Biol Biochem 101:85-95. https://doi.org/ 10.1016/j.soilbio.2016.07.005

Cade-Menun BJ (2005) Characterizing phosphorus in environmental and agricultural samples by ${ }^{31} \mathrm{P}$ nuclear magnetic resonance spectroscopy. Talanta 66(2):359-371. https:// doi.org/10.1016/j.talanta.2004.12.024

Cade-Menun BJ (2015) Improved peak identification in ${ }^{31} \mathrm{P}$ NMR spectra of environmental samples with a standardized method and peak library. Geoderma 257-258:102-114. https://doi.org/10.1016/j.geoderma. 2014.12.016

Celi L, Lamacchia S, Barberis E (2000) Interaction of inositol phosphate with calcite. Nutrient $\mathrm{Cycl}$ Agroecosyst 57:271-277. https://doi.org/10.1023/A:1009805501082

Celi L, Barberis E (2007) Abiotic reactions of inositol phosphates in soil, In: Inositol Phosphates: Linking Agriculture and the Environment (eds BL Turner, AE Richardson, E Mullaney)

Chen CR, Hou EQ, Condron LM et al (2015) Soil phosphorus fractionation and nutrient dynamics along the Cooloola coastal dune chronosequence, southern Queensland, Australia. Geoderma 257:4-13

Clarholm M, Skyllberg U (2013) Translocation of metals by trees and fungi regulates $\mathrm{pH}$, soil organic matter turnover and nitrogen availability in acidic forest soils. Soil Biol Biochem 63:142-153

Crea P, de Robertis A, de Stefano C et al (2006) Speciation of phytate ion in aqueous solution. Sequestration of magnesium and calcium by phytate at different temperatures and ionic strengths, in $\mathrm{NaCl}_{\mathrm{aq}}$. Biophys Chem 124:18-26. https://doi.org/10.1016/j.bpc.2006.05.027

Crews TE, Kitayama K, Fownes JH et al (1995) Changes in soil phosphorus fractions and ecosystem dynamics across a long chronosequence in Hawaii. Ecology 76:1407-1424. https://doi.org/10.2307/1938144

Crouse DA, Sierzputowska-Gracz H, Mikkelsen RL (2000) Optimization of sample $\mathrm{pH}$ and temperature for phosphorus-31 nuclear magnetic resonance spectroscopy of poultry manure extracts. Commun Soil Sci Plant Anal 31(1-2):229-240. https://doi.org/10.1080/ 00103620009370432

Eriksson AK, Gustafsson JP, Hesterberg D (2015) Phosphorus speciation of clay fractions from long-term fertility experiments in Sweden. Geoderma 241-242:68-74. https://doi.org/10.1016/j.geoderma.2014.10.023

Ewald J (2000) Is phosphorus deficiency responsible for the low vitality of European beech (Fagus sylvatica L.) in the Bavarian Alps? Forstwiss Centralbl 119:276-296. https:// doi.org/10.1007/BF02769143

Ewald J (2005) Ecological background of crown condition, growth and nutritional status of Picea abies (L.) Karst. In the Bavarian Alps. Eur J Forest Res 124:9-18. https://doi. org/10.1007/s10342-004-0051-5

Fardeau JC (1993) Available soil phosphate - its representation by a functional multiple compartment model. Agronomie 13:317-331

Federle TW, Livingston RJ, Wolfe LE et al (1986) A quantitative comparison of microbial community structure of estuarine sediments from microcosms and the field. Can J Microbiol 32:319-325. https://doi.org/10.1139/m86-063
Frossard E, Sinaj S (1997) The isotope exchange kinetic technique: a method to describe the availability of inorganic nutrients. Applications to $\mathrm{K}, \mathrm{P}, \mathrm{S}$ and $\mathrm{Zn}$. Isot Environ Health Stud 34:61-77

Frostegård Å, Bååth E, Tunlio A (1993) Shifts in the structure of soil microbial communities in limed forests as revealed by phospholipid fatty acid analysis. Soil Biol Biochem 25(6):723-730. https://doi.org/10.1016/00380717(93)90113-P

Giguet-Covex C, Poulenard J, Chalmin E et al (2013) XANES spectroscopy as a tool to trace phosphorus transformation during soil genesis and mountain ecosystem development from lake sediments. Geochim Cosmochim Acta 118:129-147. https://doi.org/10.1016/j.gca.2013.04.017

Gu C, Hart SC, Turner BL et al (2019) Aeolian dust deposition and the perturbation of phosphorus transformations during long-term ecosystem development in a cool, semi-arid environment. Geochim Cosmochim Acta 246:498-514. https://doi.org/10.1016/j.gca.2018.12.017

Gupta AS, Rao SK (2001) Weathering indices and their applicability for crystalline rocks. Bull Eng Geol Env 60(3):201-221. https://doi.org/10.1007/s100640100113

Gustafsson JP, Braun S, Tuyishime JRM et al (2020) A probabilistic approach to phosphorus speciation of soils using $\mathrm{P}$ K-edge XANES spectroscopy with linear combicnation fitting. Soil Systems. https://doi.org/10.3390/ soilsystems 4020026

Hamburg SP (1984) Effects of forest growth on soil nitrogen and organic matter pools following release from subsistence agriculture. In: Stone EL (ed) Forest soils and treatment impacts. University of Tennessee, Knoxville, pp 145-158

Hedley MJ, Stewart JWB, Chauhan B (1982) Changes in inorganic and organic soil phosphorus fractions induced by cultivation practices and by laboratory incubations. Soil Sci Soc Am J 46:970-976. https://doi.org/10.2136/ sssaj1982.03615995004600050017x

Heindel RC, Berry Lyons W, Welch SA et al (2017) Biogeochemical weathering of soil apatite grains in the McMurdo Dry Valleys, Antarctica. Geoderma 320:136-145. https:// doi.org/10.1016/j.geoderma.2018.01.027

Hendershot WH, Lalande H, Duquette M (2008) Ion exchange andexchangeable cations. In: Carter MR, Gregorich EG (eds) Soil sampling and methods of analysis, vol 2. CRC Press, Boca Raton, pp 197-206

Hinsinger P (2001) Bioavailability of soil inorganic P in the rhizosphere as affected by root-induced chemical changes: a review. Plant Soil 237:173-195. https://doi.org/10.1023/ A: 1013351617532

Hoffmann G (1968) Eine photometrische Methode zur Bestimmung der Phosphatase-Aktivität in Böden. Z Pflanzenern Bodenk 118(3):161-172. https://doi.org/10.1002/jpln. 19681180303

Jackson ML (1958) Soil chemical analysis. Prentice Hall. 498pp.

John MK (1970) Colorimetric determination of phosphorus in soil and plant materials with ascorbic acid. Soil Sci 109(4):214-220

Jonard M, Fürst A, Verstraeten A et al (2015) Tree mineral nutrition is deteriorating in Europe. Glob Chang Biol 21:418-430. https://doi.org/10.1111/gcb.12657 
Kaiser K, Guggenberger G, Haumaier L (2003) Organic phosphorus in soil water under a European beech (Fagus sylvatica L.) stand in northeastern Bavaria, Germany: seasonal variability and changes with soil depth. Biogeochemistry 66:287-310. https://doi.org/10.1023/B:BIOG. 0000005325.86131.5f

Klysubun W, Sombunchoo P, Deenan W et al (2012) Performance and status of beamline BL8 at SLRI for X-ray absorption spectroscopy. J Synchrotron Rad 19:930-936. https://doi.org/10.1107/S0909049512040381

Klysubun W, Tarawarakarn P, Thamsanong N et al (2019) Upgrade of SLRI BL8 beamline for XAFS spectroscopy in a photon energy range of 1-13 keV. Rad Phys Chem. https://doi.org/10.1016/j.radphyschem.2019.02.004

Kohlpaintner M, Göttlein A (2020) Nährstoff- und Wasserhaushalt des Systems Alpenhumus “ In: Ewald J, Göttlein A, Prietzel J, Kohlpaintner $M$ et al Alpenhumus als klimasensitiver C-Speicher und entscheidender Standortfaktor im Bergwald. Forstl Forschungsber München 220:61-100

Kouno K, Tuchiya Y, Ando T (1995) Measurement of soil microbial biomass phosphorus by an anion-exchange membrane method. Soil Biol Biochem 27(10):1353-1357. https://doi.org/10.1016/0038-0717(95)00057-L

Küfmann C (2006) Measurement and climatic control of eolian sedimentation on snow cover surface in the Northern Calcareous Alps (Wetterstein-, Karwendel and Berchtesgadener Alps, Germany). Zeitschr Geomorphol 50:245-268

Lajtha K, Schlesinger WH (1988) The biogeochemistry of phosphorus cycling and phosphorus availability along a desert soil chronosequence. Ecology 69(1):24-39. https:// doi.org/10.2307/1943157

Lang F, Bauhus J, Frossard E et al (2016) Phosphorus in forest ecosystems: new insights from an ecosystem nutrition perspective. J Plant Nutr Soil Sci 179:129-135. https://doi. org/10.1002/jpln.201500541

Lang F, Krüger J, Amelung W et al (2017) Soil phosphorus supply controls $\mathrm{P}$ nutrition strategies of beech forest ecosystems in Central Europe. Biogeochemistry 136:5-29. https://doi.org/10.1007/s10533-017-0375-0

Lim CH, Jackson ML (1982) Dissolution for total elemental analysis In: Methods of Soil Analysis Part II. Chemical and Microbiological Properties. Ed. Page, AL, American Society of Soil Science. Part 2. Agron. Monogr. 9. ASA and SSSA, Madison, WI

Margesin R (1996) Phosphodiesterase activity. In: Schinner F, Öhlinger R, Kandeler E, Margesin R (eds) Methods in Soil Biology. Springer, Heidelberg, pp 217-219

McKercher RB, Anderson G (1989) Organic phosphate sorption by neutral and basic soils. Commun Soil Sci Plant Anal 20(7-8):723-732. 00103628909368112

Mehra OP, Jackson ML (1960) Iron oxide removal from soils and clay by a dithionite-citrate system buffered with sodium bicarbonate. Clays Clay Miner 7:317-327

Mellert KH, Ewald J (2014) Nutrient limitation and site-related growth potential of Norway spruce (Picea abies [L.] Karst) in the Bavarian Alps. Eur J Forest Res 133:433-451. https://doi.org/10.1007/s10342-013-0775-1
Mendez JC, Hiemstra T (2020) Ternary complex formation of phosphate with $\mathrm{Ca}$ and $\mathrm{Mg}$ ions binding to ferrihydrite: experiments and mechanisms. ACS Earth Space Chem 4:525-557. https://doi.org/10.1021/acsearthspacechem. $9 \mathrm{~b} 00320$

Milnes A, Fitzpatrick R (1989) Titanium and zirconium minerals. In Minerals in Soil Environments (eds JB Dixon and SB Weed). https://doi.org/10.2136/sssabookser1.2ed.c23

Murphy J, Riley JP (1962) A modified single solution method for the determination of phosphate in natural waters. Anal Chim Acta 27:31-36. https://doi.org/10.1016/S00032670(00)88444-5

Nahm M, Holst T, Matzarakis A et al (2006) Soluble N compound profiles and concentrations in European beech (Fagus sylvatica L.) are influenced by local climate and thinning. Eur J Forest Res 125:1-14

Niederberger J, Kohler M, Bauhus J (2019) Distribution of phosphorus fractions with different plant availability in German forest soils and their relationship with common soil properties and foliar P contents. Soils 5:189-204. https://doi.org/10.5194/soil-5-189-2019

Oberson A, Joner E (2005) Microbial turnover of phosphorus in soil. In: Turner BL, Frossard E, Baldwin DS (eds) Organic phosphorus in the environment. CABI, Wallingford, UK, pp 133-164

Öhlinger R (1996) Phosphomonoesterase activity with the substrate phenylphosphate. In: Schinner F, Öhlinger R, Kandeler E, Margesin R (eds) Methods in Soil Biology. Springer, Heidelberg, pp 210-213

Ohno T, Zibilske LM (1991) Determination of low concentrations of phosphorus in soil extracts using malachite green. Soil Sci Soc Am J 55(3):892. https://doi.org/10.2136/ sssaj1991.03615995005500030046x

Olsen SR, Cole CV, Watanabe FS, Dean LA (1954) Estimation of available phosphorus in soils by extraction with sodium bicarbonate. USDA Circular 939. U.S. Government Printing Office, Washington D.C.

Pastore G, Weig AR, Vazquez E, Spohn M (2022) Weathering of calcareous bedrocks is strongly affected by the activity of soil microorganisms. Geoderma 405:115408. https://doi. org/10.1016/j.geoderma.2021.115408

Porder S, Ramachandran S (2013) The phosphorus concentration of common rocks-a potential driver of ecosystem $P$ status. Plant Soil 367(1-2):41-55

Prietzel J (2010) Schutzwälder der Nördlichen Kalkalpen: Verjüngung, Mikroklima, Schneedecke und Schalenwild. Schweiz Zeitschr Forstwes 161:11-22

Prietzel J, Ammer C (2008) Montane Bergmischwälder der Bayerischen Kalkalpen: Reduktion der Schalenwild-dichte steigert nicht nur den Verjüngungserfolg, sondern auch die Bodenfruchtbarkeit. Allg Forst Jagdztg 179:104-112

Prietzel J, Klysubun W (2018) Phosphorus K-edge XANES spectroscopy has probably often underestimated iron oxyhydroxide-bound $\mathrm{P}$ in soils. J Synchrotron Rad 25:1736-1744. S1600577518013334

Prietzel J, Stetter U (2010) Long-term trends of phosphorus nutrition and topsoil phosphorus stocks in unfertilized and fertilized Scots pine (Pinus sylvestris) stands at two sites in Southern Germany. Forest Ecol Manage 
259(6):1141-1150. https://doi.org/10.1016/j.foreco.2009. 12.030

Prietzel J, Dümig A, Wu Y et al (2013) Synchrotron-based P K-edge XANES spectroscopy reveals rapid changes of phosphorus speciation in the topsoil of two glacier foreland chronosequences. Geochim Cosmochim Acta 108:154-171. https://doi.org/10.1016/j.gca.2013.01.029

Prietzel J, Christophel D, Traub C et al (2015) Regional and site related patterns of soil nitrogen, phosphorus, and potassium stocks and Norway spruce nutrition in mountain forests of the Bavarian Alps. Plant Soil 386:151-169. https://doi.org/ 10.1007/s11104-014-2248-9

Prietzel J, Harrington G, Häusler W et al (2016a) Reference spectra of important organic and inorganic phosphate binding forms for soil $\mathrm{P}$ speciation using synchrotronbased K-edge XANES spectroscopy. J Synchrotron Rad 23:532-544. https://doi.org/10.1107/S1600577515023085

Prietzel J, Zimmermann L, Schubert A, Christophel D (2016c) Organic matter losses of German Alps forest soils since the 1970s most likely caused by warming. Nature Geosci 9:543-548. https://doi.org/10.1038/ngeo2732

Prietzel J, Prater I, Colocho Hurtarte LC et al (2019) Site conditions and vegetation determine phosphorus and sulfur speciation in soils of Antarctica. Geochim Cosmochim Acta 246:339-362. https://doi.org/10.1016/j.gca.2018.12. 001

Prietzel J, Klysubun W, Werner F (2016) Speciation of phosphorus in temperate zone forest soils as assessed by combined wet-chemical fractionation and XANES spectroscopy. J Plant Nutr Soil Sci 179:168-185

Prietzel J, Falk W, Reger B et al (2020) Half a century of Scots pine forest ecosystem monitoring reveals long-term effects of atmospheric deposition and climate change. Glob Chang Biol 26(10):5796-5815

Rehfuess KE (1990) Waldböden - Entwicklung. Eigenschaften und Nutzung, Pareys Studientexte Paul Parey, Hamburg, Berlin

Rodionov A, Bauke SL, von Sperber C et al (2020) Biogeochemical cycling of phosphorus in subsoils of temperate forest ecosystems. Biogeochemistry 150:313-328. https:// doi.org/10.1007/s10533-020-00700-8

Saunders WMH, Williams EG (1955) Observation on the determination of total organic phosphorus in soils. J Soil Sci 6(2):254-267. https://doi.org/10.1111/j.1365-2389. 1955.tb00849.x

Schubert A (2002) Bayerische Waldboden-Dauerbeobachtungsflächen-Bodenuntersuchungen. Forstl Forschungsber München 187

Schwertmann U (1964) Differenzierung der Eisenoxide des Bodens durch Extraktion mit Ammoniumoxalat-Lösung. Z Pflanzenernaehr Dueng Bodenk 105(3):194-202. https:// doi.org/10.1002/jpln.3591050303

Selmants PC, Hart SC (2010) Phosphorus and soil development. Does the Walker and Syers model apply to semiarid ecosystems? Ecology 91(2):474-484

Sohrt J, Lang F, Weiler M (2017) Quantifying components of the phosphorus cycle in temperate forests. Wileys Interdisciplinary Reviews Water 4:e1243. https://doi.org/10. 1002/wat 2.1243
Stahr K, Böcker R (2014) Landschaften und Standorte BadenWürttembergs. Exkursionsführer. Hohenheimer Bodenkundl Hefte

Stock SC, Koester M, Boy J et al (2021) Plant carbon investment in fine roots and arbuscular mycorrhizal fungi: a crossbiome study on nutrient acquisition strategies. Sci Tot Environ 781:146748. https://doi.org/10.1016/j.scitotenv. 2021.146748

Sudom MD, Arnaud RJS (1971) Use of quartz, zirconium, and titanium as indices in pedological studies. Can J Soil Sci 51:385-396

Sumann M, Amelung W, Haumaier L et al (1998) Climatic effects on soil organic phosphorus in the North American great plains identified by phosphorus-31 nuclear magnetic resonance. Soil Sci Soc Am J 62(6):1580. https://doi.org/ 10.2136/sssaj1998.03615995006200060015x

Talkner U, Meiwes KJ, Potocic N et al (2015) Phosphorus nutrition of beech (Fagus sylvatica L.) is decreasing in Europe. Ann For Sci 72(7):919-928. https://doi.org/10. 1007/s13595-015-0459-8

Tiessen H, Moir JO (1993) Characterization of available P by sequential extraction. In: Carter MR (ed) (1993) Soil Sampling and Methods of Analysis. Lewis Publishers, Boca Raton, pp 75-86

Turner BL (2004) Optimizing phosphorus characterization in animal manures by solution phosphorus-31 nuclear magnetic resonance spectroscopy. J Environ Qual 33(2):757-766. https://doi.org/10.2134/jeq2004.7570

Turner BL, Paphazy MJ, Haygarth PM et al (2002) Inositol phosphates in the environment. Philos T R Soc London B 357:449-469

Turner BL, Condron LM, Richardson SJ et al (2007) Soil organic phosphorus transformations during pedogenesis. Ecosystems 10(7):1166-1181. https://doi.org/10.1007/ s10021-007-9086-Z

Turner BL, Lambers H, Condron LM et al (2013) Soil microbial biomass and the fate of phosphorus during long-term ecosystem development. Plant Soil 367:25-234. https:// doi.org/10.1007/s11104-012-1493-Z

Turner S, Schippers S, Meyer-Stüve S et al (2014) Mineralogical impact on long-term patterns of soil nitrogen and phosphorus enzyme activities. Soil Biol Biochem 68:31-43. https://doi.org/10.1016/j.soilbio.2013.09.016

Uhlig D, Amelung W, von Blanckenburg F (2020) Mineral nutrients sourced in deep regolith sustain long-term nutrition of mountainous temperate forest ecosystems. Glob Biogeochem Cycl. https://doi.org/10.1029/ 2019GB006513

Vadeboncoeur MA, Hamburg SP, Blum JD et al (2012) The quantitative soil pit method for measuring below-ground carbon and nitrogen stocks. Soil Sci Soc Am J 76:2241-2255. https://doi.org/10.2136/sssaj2012.0111

Vance ED, Brookes PC, Jenkinson DS (1987) An extraction method for measuring soil microbial biomass C. Soil Biol Biochem 19:703-707. https://doi.org/10.1016/00380717(87)90052-6

Vincent AG, Vestergren J, Gröbner G et al (2013) Soil organic phosphorus transformations in a boreal forest chronosequence. Plant Soil 367:149-162. https://doi.org/10.1007/ s11104-013-1731-z 
Walker TW, Syers JK (1976) The fate of phosphorus during pedogenesis. Geoderma 15:1-19. https://doi.org/10.1016/ 0016-7061(76)90066-5

Wan B, Yan Y, Liu F et al (2016) Surface adsorption and precipitation of inositol hexakisphosphate on calcite: a comparison with orthophosphate. Chem Geol 421:103-111. https://doi.org/10.1016/j.chemgeo.2015.12.004

Wang L, Missong A, Amelung W et al (2020) Dissolved and colloidal phosphorus affect $\mathrm{P}$ cycling in calcareous forest soils. Geoderma 375:114507. https://doi.org/10.1016/j. geoderma.2020.114507

Wardle DA, Walker LR, Bardgett RD (2004) Ecosystem properties and forest decline in contrasting long-term chronosequences. Science 305:509-513. https://doi.org/ 10.1126/science. 1098778

Werner F, Prietzel J (2015) Standard protocol and quality assessment of soil phosphorus speciation by $\mathrm{P}$ K-edge XANES spectroscopy. Environ Sci Technol 49:10521-10528. https://doi.org/10.1021/acs.est.5b03096
White DC, Davis WM, Nickels JS et al (1979) Determination of the sedimentary microbial biomass by extractable lipid phosphate. Oecologia 40:51-62. https://doi.org/10.1007/ BF00388810

WRB (2015) World reference base for soil resources 2014, update 2015 International soil classification system for naming soils and creating legends for soil maps. World soil resources reports, FAO, Rome

Wu J, Joergensen RG, Pommerening B et al (1990) Measurement of soil microbial biomass-C by fumigation-extraction-an automated procedure. Soil Biol Biochem 22(8):1167-1169. https://doi.org/10.1016/00380717(90)90046-3

Zöttl H (1965) Zur Entwicklung der Rendzinen in der subalpinen Stufe. Z Pflanzenern Bodenkde 110:109-134

Publisher's Note Springer Nature remains neutral with regard to jurisdictional claims in published maps and institutional affiliations. 